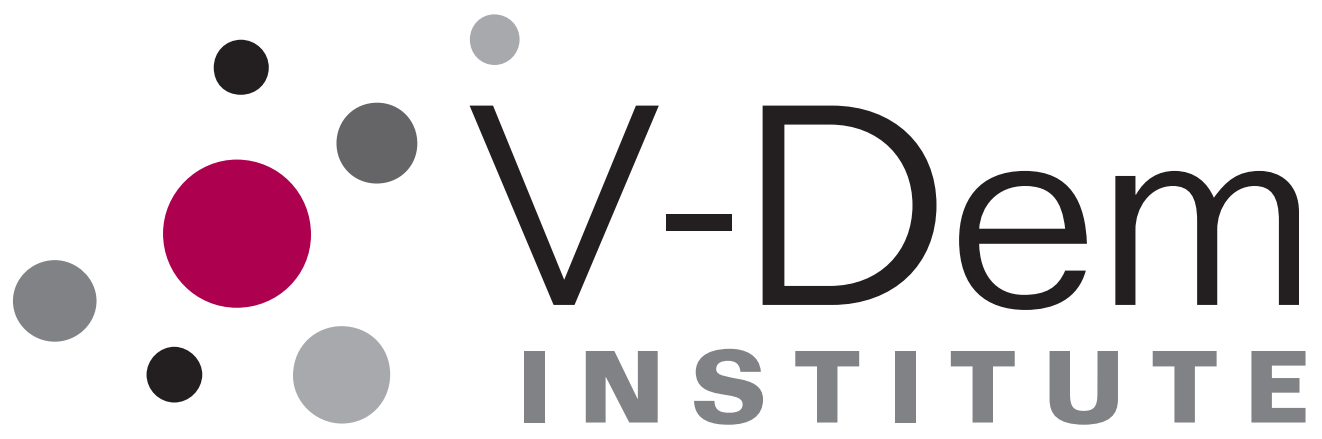

0000000000000000000 000000000000000000000000 18)

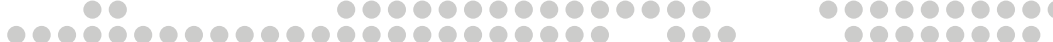

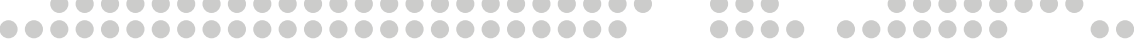

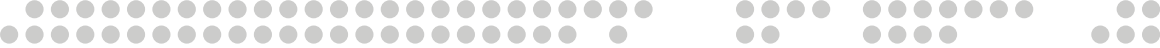

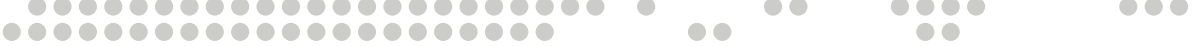

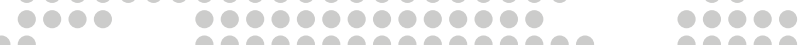

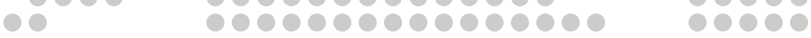
000000000000000000000000 0000000000000000000000000

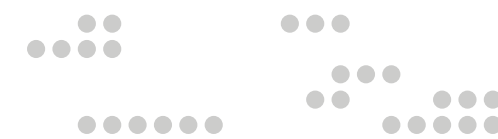

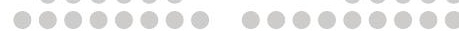
$1000000000009000 \mathrm{c}$ $000000000000000000 \mathrm{C}$

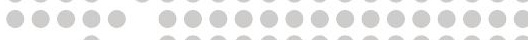
-

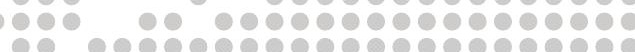

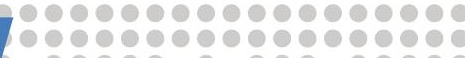

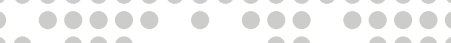

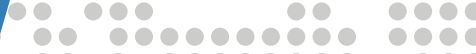
10 00000000 100

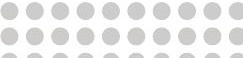
and Interstate Conflict

Tore Wig, Sirianne Dahlum, Carl Henrik Knutsen, Magnus Bergli Rasmussen

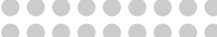

1009000

000000

000900

80080

000

000

10

10

10

8

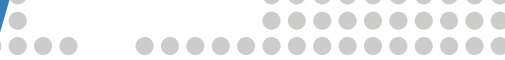

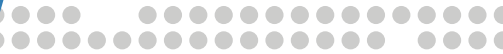

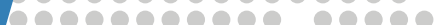

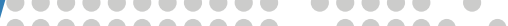

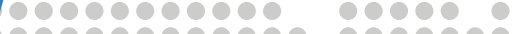

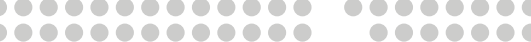
60900000000000 000000

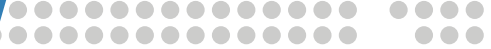
1000000000000000 20000000000000000000

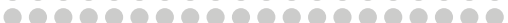
-

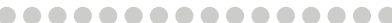

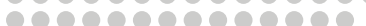

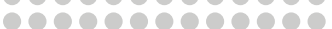

10000000000

00090000000 0000000000 -

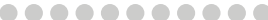

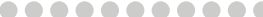
roposoror -

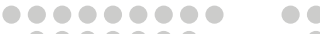

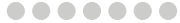
0000 000000 1000 ○ी 
Varieties of Democracy (V-Dem) is a new approach to conceptualization and measurement of democracy. The headquarters - the V-Dem Institute - is based at the University of Gothenburg with 19 staff. The project includes a worldwide team with six Principal Investigators, 14 Project Managers, 30 Regional Managers, 170 Country Coordinators, Research Assistants, and 3,000 Country Experts. The V-Dem project is one of the largest ever social science research-oriented data collection programs.

Please address comments and/or queries for information to:

V-Dem Institute

Department of Political Science

University of Gothenburg

Sprängkullsgatan 19, PO Box 711

SE 40530 Gothenburg

Sweden

E-mail: contact@v-dem.net

V-Dem Working Papers are available in electronic format at www.v-dem.net.

Copyright (C2020 by authors. All rights reserved. 


\title{
Cui Bono? Business Elites and Interstate Conflict
}

\author{
Tore Wig ${ }^{1}$, Sirianne Dahlum ${ }^{2}$, Carl Henrik Knutsen ${ }^{1}$, and Magnus Bergli \\ Rasmussen $^{1}$ \\ ${ }^{1}$ Department of Political Science, University of Oslo \\ ${ }^{2}$ Peace Research Institute Oslo, PRIO
}

August 24, 2020

\begin{abstract}
We address how regime supporters affect war-making by re-opening a classic debate on business elites and their influence on states' conflict behavior. Imperialist theories contend that business elites encourage executives to undertake military expeditions to "open up" foreign markets, while "capitalist peace" arguments emphasize that business elites have economic incentives to work for peace. We synthesize these arguments and propose that countries become more belligerent, in general, when business elites enter regime support coalitions, but not towards other business-supported regimes. We use recently compiled data on social groups in regime support coalitions, covering 200 polities across 1789-2018, to test implications of our argument. We find that businesssupported regimes are more likely to initiate armed conflict, but not against other countries with business-elite supported regimes. We also find support for additional implications, for instance pertaining to how the belligerence of business-supported regimes depends on existing trade relationships.
\end{abstract}

We have received invaluable comments and suggestions from Tobias Rommel, Rick Wilson, Kelly McMann, Scott Gates, Kristian Skrede Gleditsch, Tatjana Stankovic, Håvard Mokleiv Nygård, Johannes Lindvall, Johannes Gerschewski, Christian Houle, Michael Wahman, Jeff Conroy-Krutz, and Masaaki Higashijima as well as participants at the 2018 Historical V-Dem Workshop in Oslo, the International Security Program Seminar at the Belfer Center, Harvard Kennedy School, the NEPS Conference 2018 in Verona, the APSA Annual Meeting 2018 in Boston, V-Dem Conference 2019 in Gothenburg, 2019 Workshop on Comparative Authoritarianism at the TUM School of Governance, Munich, and the Michigan State University Comparative Politics Workshop. 


\section{Introduction}

Decades of research have that domestic political institutions of various kinds affect the interstate conflict behavior of states. Domestic constraints on executives, in particular, have been proposed to explain the war behavior of both democracies (Hegre, 2014) and dictatorships (Weeks, 2012, 2014). ${ }^{1}$ Yet, decision-making on war and peace is influenced also by other domestic political features than structural features pertaining to a country's institutions. What types of actors wield power also matters. In this paper, we turn the focus towards who holds influence within (democratic and autocratic) institutions. More specifically, we explore how the economic motivations of business elites, and their sway over political leaders, affect the war behavior of states under different conditions.

History provides several examples suggesting that business elites influence political leaders' decisions to go to war. For instance, when the United States invaded Iraq in 2003, vocal critics suggested that the invasion was motivated by the interests of "Big Oil", which was deeply entrenched in the Bush administration. ${ }^{2}$ Also several 19th century conflicts have been attributed to the interests and influence of business elites, including the First Opium War initiated by Britain against China (Greenberg, 1969) and the War of the Pacific - also known as the "Salpeter War" or "Ten Cents War" - from 1879-1883, pitting Chile against Bolivia and Peru (Farcau, 2000). Also smaller-scale conflicts such as the "opening" of Japanese cities to trade by the Perry Expedition in 1854 have been linked to profit motives of business elites and cooperating governments. Lenin (1999), for example, proposed that politicians influenced by the interests of capital would initiate armed conflicts to open up new markets and colonize economically less developed areas. Thus, in order to understand the outbreak of conflict observers have, throughout history, asked: cui bono? Who profits?

Still, the archetypal image of warmongering business elites contrasts with another widely held view suggesting that business elites may have strong economic interests to preserve the peace. In 1910 - in the same decade as Lenin published his theory on Imperialism - Norman Angell published "The Great Illusion", arguing that European capitalists had strong incentives to avoid war, notably due to the profits stemming from peace under conditions of interdependent markets (Angell, 1938). Contemporary conflict scholars refined this argument, finding systematic empirical evidence for the pacifying effects of, for example, trade (Russett and Oneal, 2001) and financial integration (Gartzke, 2007). These "capitalist peace" arguments suggest that business interests, when empowered politically, could have

\footnotetext{
${ }^{1}$ For a recent synthesis, see Hyde and Saunders (2020).

${ }^{2}$ See Vidal (2007). For an alternative explanation of the war Debs and Monteiro (c.f., 2014).
} 
pacifying effects.

We synthesize these two strands of argument; although reaching different conclusions, the "imperialist" and "capitalist peace" views share two key features. First, they both rely on a model of politics whereby state executives somehow react strongly to the preferences of business actors. Second, both views assume that business elites' preferences on matters of war and peace will depend on how they anticipate war to affect their firms' profits. We provide a more detailed theoretical account of when and how business elites shape war behavior, that integrates the two views. In doing so, we propose that the ability of business elites to influence decisions of war and peace depends on whether or not they are part of a (autocratic or democratic) regime's support coalition. This aligns with insights linking decision-making and policy-outcomes not only to the interests of the principal leader but also the coalition that s/he relies upon to stay in power (e.g., Bueno de Mesquita et al., 2003; Bueno de Mesquita and Smith, 2012; Svolik, 2012; Weeks, 2014; Hyde and Saunders, 2020). Further, we highlight that the profit-motive of business elites may, especially depending on the economic situation of the "target country" in question, sometimes be a force for peace and at other times a force for war.

We test different empirical implications from our argument, and thus offer the first direct large-n investigation of the link between business elites' role in regime support coalitions and interstate conflict behavior. We draw on recently compiled data in version 9 of the Varieties of Democracy (V-Dem) dataset (Coppedge, Gerring, Knutsen, Lindberg, Teorell, Altman, Bernhard, Fish, Glynn, Hicken, Lührmann, Marquardt, McMann, Pemstein, Seim, Sigman, Skaaning, Staton, Wilson, Cornell, Gastaldi, Gjerlow, Ilchenko, Krusell, Maxwell, Mechkova, Medzihorsky, Pernes, von Romer, Stepanova, Sundstrom, Tzelgov, Wang, Wig and Ziblatt, 2019; Coppedge, Gerring, Knutsen, Lindberg, Teorell, Marquardt, Medzihorsky, Pemstein, Pernes, von Römer et al., 2019; Pemstein et al., 2018) registering the presence and status of business elites in regime support coalitions of almost 200 countries, with maximum time series extending from 1789-2018. We combine these data with measures of militarized interstate disputes from Correlates of War (COW) (Sarkees and Wayman, 2010), in a directed-dyads framework. We thereby augment previous empirical studies of "the capitalist peace" (see Schneider and Gleditsch, 2010), which have attempted to capture the power and interests of economic actors by using structural variables, such as trade volume within dyads (Russett and Oneal, 2001), size of the financial sector (Gartzke, 2007), or how contract intensive economies are (Mousseau, 2013). While these approaches have offered important insights, they do not adequately account for the political positions of business elites within a 
regime; in other words, they do not satisfactorily model business elites as actors. Our study thus responds to Schneider (2017), who recently surveyed the capitalist-peace literature and recommended that "empirical tests of the proposed causal mechanism should rely on data sets in which capitalists appear as actors and not as "structures"" (p.1).

In brief, we find that regimes backed by business elites are, generally, more likely to initiate militarized interstate disputes, supporting the belligerent, "imperialist" view of business elites. But, we also find clear evidence that business-supported regimes are systematically less likely to initiate disputes against another country where the regime is backed by business elites, providing support for the capitalist peace thesis. These results hold up to controlling for standard covariates such as distance between countries and material capabilities and are fairly robust to alternative specifications. Testing additional implications and scope conditions, we find that the relationship holds both before and after WWI, and that it interacts with trade relationships, as anticipated: Business-business dyads are much less likely to end up in conflicts when trade is high in the dyad, and business-supported regimes are more likely to attack non-business regimes when pre-existing trade is low. These findings offer new lessons for long-standing discussions on how business interests shape war behavior, how the proposed pacifying effect of business elites depends on internal power dynamics (i.e., the extent to which business elites can influence domestic regimes), and considerations about economic costs and gains from different types of armed conflict.

\section{Background}

Explanations of war centering on domestic politics have a long tradition (see, e.g., Waltz, 1959; Levy and Thompson, 2011; Bueno de Mesquita and Smith, 2012). Key notions underpinning such theories are that executives are motivated by staying in office and that they - to varying degrees - are responsive to coalitions of societal actors that can have them removed (Hyde and Saunders, 2020). Chances of removal increase when leaders take actions that displease elites, for example not following up on explicit commitments to respond to

foreign threats of military action, thus incurring "audience costs" (Fearon, 1994), or lose costly wars. In such cases, actors with the capacity to remove the leader may create ex ante and ex post costs to military action. Empowered elites and other actors thus constrain the action space of the executive, and use this power to steer policy in their preferred direction.

Yet, most empirical contributions on leader constraints focus on institutions. Notably, a prominent explanation for the "democratic peace" maintains that leaders face greater 
institutional constraints in democratic systems (Hegre, 2014; Hegre, Bernhard and Teorell, 2020). These shackles, in turn, make democracies more likely to opt out of costly wars (especially with other democracies) and settle disputes peacefully (Choi, 2010; Bueno de Mesquita et al., 1999). Variation in institutional constraints placed on leaders have recently been invoked to explain variation in conflict behavior also among dictatorships (Weeks, 2014, 2012; Colgan and Weeks, 2015); constraints placed on leaders by alternative, power-balancing institutions, including capable legislatures or dominant regime parties, may influence even the belligerence of non-democracies. Hyde and Saunders (2020) synthesize arguments across different regime types, outlining a continuum of "domestic audience constraints" where both democracies and dictatorships vary in the degree to which leaders are curtailed.

Yet, at the core of these arguments on institutional constraints lie (often implicit) assumptions about particular social actors who establish and populate the different constraining institutions, and have differing preferences from the leader on matters of peace and war. These actors presumably use their political clout - coming from being part of the regime's support coalition and controlling key institutions - to translate private preferences into foreign policy decisions. In order to better understand states' conflict behavior, we should explicitly consider the preferences of the key actors whom leaders depend on to retain power.

Whereas case-evidence (e.g. Fischer, 1967; Clark, 2012) suggests that the identity and social characteristics of actors embedded in regime support coalitions influence conflict behavior, the more general theoretical and large-n empirical studies on interstate war have, so far, not sufficiently detailed who these constraining actors are, and how they affect conflict behavior. Instead, the general conflict literature has focused on other features of support coalitions, notably their size (Bueno de Mesquita et al., 2004). There are recent exceptions in the study of war behavior in autocracies, where the identity of elite actors has been approached indirectly by studying autocracy types and distinguishing between military-, personalist- and party-based regimes (Weeks, 2008, 2014, 2012; Colgan and Weeks, 2015). Related studies of democracy and conflict have mostly operated with abstract notions and distinctions between institutional actors (such as "veto players"; e.g., Choi, 2010), horizontal and social accountability (Hegre, Bernhard and Teorell, 2020), and vertical constraints from the broader electorate (Goldsmith et al., 2017; Baum and Potter, 2015). Yet, this literature remains mute on questions concerning how the more specific social identities and economic interests of regime supporters influence conflict behavior.

Against this backdrop, we present a theoretical argument considering how the preferences of members of the regime's support coalition influence conflict behavior. More specifically, 
we focus on business elites, typically urban investors or owners of large firms. As noted in the introduction, the role of business elites in international war was hotly debated in earlier decades, and we draw on these early insights when constructing our argument. Marxist theories of war, notably including Lenin's (1999) Imperialist theory implying that capitalist societies will be more war-prone, was that business elites have much to gain from war. On Lenin's view, politicians acting on behalf of the interests of capital would engage in conflicts to colonize countries, with the purpose of opening up new markets (see also Hobson, 1902; Luxemburg, 1913). Presumably, competition for colonies would ultimately also lead to wars between capitalist countries "competing" for such markets. Also Hilferding's (1985) "theory of imperialism" suggests that capitalist-supported regimes seek to expand markets by violent means to increase profits and Galtung's (1971) "structural theory of imperialism" proposes that capitalist regimes in the "center" use violent means to subjugate and exploit states in the "periphery", to serve their economic interests. Hence, conflict may reflect the advancement of business interests.

In contrast, other scholars have highlighted the interests of capital in promoting peace rather than war. Early contributions to "capitalist peace theory" (e.g., Angell, 1938; Schumpeter, 1955/1919) pointed out the economic costs of war, and several recent contributions echo these sentiments, emphasizing the costs of interrupting transnational economic interactions. Hence, business elites might incur various costs from war that exceed potential benefits, notably because war disrupts trade (c.f., Anderton and Carter, 2001; Gowa and Hicks, 2017). Further, war may lower confidence in markets and thus reduce investments and increase capital flight (Lensink, Hermes and Murinde, 2000). Further, fighting - especially on one's own territory - may destroy key infrastructure and deplete existing stocks of physical capital. Further, losses in human capital and labor supply from soldiers dying in battle increase labor costs (e.g., Scheidel, 2018). Thus, war can be "bad for business".

\section{$3 \quad$ Business elites and conflict}

Our argument highlights the various pecuniary incentives of business elites reviewed above, their ability to influence policy, and leader decisions on war and peace. Hence, our argument draws on the costs-of-war mechanisms from the capitalist peace tradition, ${ }^{3}$ and integrate

\footnotetext{
${ }^{3}$ Recent arguments have gone beyond addressing direct costs of war, and highlight other mechanisms that likely also contribute to the "capitalist peace". Gartzke (2007) proposes that capitalist (open) economies reveal more information about the intentions of leaders, reducing private information and opportunistic bluffing that often induce war. Mousseau (2013) proposes that the contractual integration of capitalist
} 
them with the reviewed gains-from-war mechanisms proposed by Lenin (1999), Galtung (1971) and others. In short, we detail how profit-motivated business elites weigh the different expected costs and revenues of war, preferring war when expected profits are positive and peace otherwise. Further, we describe how the presence of business elites in the regime's support coalition allow these pecuniary interests to translate into policy decisions on initiating or avoiding conflict. While we focus on business elites in this paper, our framework is flexible and can be specified for any support group where we can outline the expected gains and costs associated with warfare.

\subsection{A simple model of support coalition incentives and war-making}

Starting with the conceptual building blocks, we define a 'political regime' as the set of rules that regulate who are chosen as political leaders, and how they are selected into and out of power (Geddes, Wright and Frantz, 2014; Djuve, Knutsen and Wig, 2020). Such rules can be formal, for instance embedded in a constitution, but they can also be informal rules that are practiced and enforced by a broader or narrower group of key actors. A 'support group' is a social group - characterized by class, common profession, or some other politically salient social marker such as ethnicity or religion - whose manifest or latent support strongly enhances the regime's prospects of survival. ${ }^{4}$ Examples of support groups are party elites in current Communist China, land-owning elites and the military in early 19th century Prussia, and a particular ethnic/religious group (the Alawites) in the present Baathist regime in Syria. The social group that we focus on, which may or may not be a support group for a regime at a given point in time, is 'business elites'. We delineate this group to cover owners, managers and major investors in relatively large enterprises, financiers, and other leaders of industry, all of which are typically concentrated in urban centers. We exclude from the definition large-scale land-owners and other rural elites, and treat them as a separate social group in our empirical study. Similarly, we distinguish "urban middle classes", including owners of small enterprises and salaried professionals, from business elites.

We assume that wars are ultimately decided on by executives. Historically, decisions on war and peace have often been a constitutional prerogative of chief executives. Also in systems without constitutions, leaders (perhaps together with a small council of advisers) are, in practice, central in war-making decisions. Yet, even if the ultimate decision lies with

economies is decisive in causing peace.

${ }^{4} \mathrm{~A}$ 'support coalition' consists of all relevant support groups for the regime, at a particular point in time. Hence, a support coalition can contain one or several support groups, and one (or a few) support group(s) may be relatively more important to regime survival than others. 
the leader, support groups can influence such decisions through different means. They can pressure the leader ex ante to enter or avoid a war, and punish the leader ex-post should $\mathrm{s} /$ he enter a war that they disagree with or that ends with a bad outcome (c.f Weeks, 2014). We construe support group power in terms of the "costs" that it can impose on the leader. These costs could be related to support groups refusing to co-operate if war breaks out (e.g. withholding loans or taxes), supporting an opponent in the next election, or trying to remove the leader through orchestrating or bankrolling a coup d'état. Such supportgroup imposed costs add to other costs of war (or peace), from the leader's viewpoint, thus affecting decision calculuses. In some instances, support groups can influence policy also more indirectly by formalizing decision-making procedures (e.g. ratification or veto procedures), by institutionalizing effective monitoring of executive decisions, and by delegating decisionmaking power in certain areas (e.g. the financing of wars) to other entities than the executive branch.

Support groups presumably influence policy according to their private preferences. What ultimately matters for support group preferences on decisions on peace and war, we assume, is the difference between the expected gains $(E(g))$ and losses $(E(l))$ of a particular conflict. ${ }^{5}$ When the group considers $E(g)-E(l)>0$, it will not attempt to constrain leaders deciding to go to war, and it may even expend resources to push for conflict, in proportion to the expected gains. If $E(g)-E(l)<0$, the group will try to prevent a war.

In this simplified scheme, we can construe "gains" and "losses" broadly to include both monetary and non-pecuniary factors. For instance, if industrial workers are enlisted in armies and sent off to battle, a high body count represents a high non-pecuniary cost to this group. Likewise, increased prestige or political influence after a (successful) war may be a relevant non-pecuniary expected gain for military officers. In our discussion of business elites, however, we simplify and focus exclusively on monetary costs, for different kinds of warfare, thus following core assumptions in both the "capitalist peace" and "imperialist" literatures: Business owners maximize expected profits, $E(\pi)=E(r)-E(c)$, where $E(r)$ is expected revenue and $E(c)$ is expected monetary costs. If initiating a war increases expected profits, business elites presumably favor it, or favor actions that heighten the risk of war such as threats.

\footnotetext{
${ }^{5}$ Expected gains and costs are aggregated over the probability distributions that actors have over the potential outcomes that can follow from war. This framework could easily be extended to incorporate risk aversion - i.e., actors would willingly pay a premium to avoid the worst outcomes. Yet, we simplify and discuss as if actors are risk neutral.
} 


\subsection{The incentives of business elites}

Standard microeconomic theory (see, e.g., Varian, 1992) can help us to understand how profit-maximizing business elites view wars under different scenarios. Let us list some relevant insights for our purposes: First, a monopoly situation yields strictly higher revenue (and thus profit) than an oligopoly situation (two or a few competing firms), which, in turn, gives higher revenue than a "free-market" situation with numerous competing firms. Second, neoclassical trade theory suggests that even in industries with constant or decreasing returns to scale, i.e., marginal costs are constant or increase in produced units, opening up to international trade benefits capital owners from capital-intensive countries. Third, when there are increasing returns to scale in production, firms from both capital-intensive and labor-intensive countries may reap higher profits from accessing larger markets, due to falling marginal costs with higher production volumes. Fourth, "gravity models" of trade (e.g., Feenstra, 2003) posit that trade volumes are generally higher between geographically close economies. Regarding foreign investments, micro-economic theory predicts that capital investments in initially capital-scarce markets (typically poor economies) yield higher returns to investment. Further, prominent theories of foreign direct investment (FDI) suggest that businesses often have strong incentives to locate parts of their operations in countries with "location-specific advantages" (Dunning, 1993), including abundant natural resources.

Against this background, let us reconsider the long-standing "imperialist argument" on business elites and war. Lenin (1999), for example, suggests that business elites consider warfare as a profitable means to expand markets and acquire high rents on capital invested in new locations that are not (yet) fully integrated in global markets (see also Hobsbawm, $2010 a, b)$. Under these conditions, the above-listed insights from economic theory do, indeed, suggest that business elites can gain from war through various pathways.

First, military coercion can be used to give (initiator-country) business elites market access, thus increasing expected profits $(E(\pi))$. State can use military force short of invasion to intimidate a "closed economy" to open up its markets to imports (increasing $E(r)$ ) or give initiator-country companies control over key inputs to production through foreign ownership or forced exports (reducing E(c))). The "Gunboat Diplomacy" practiced by the British during the First Opium War (Wong, 2000), when Britain forced China to set tariffs at $5 \%$ and open several ports to foreign trade, is one example. Actions can also take the form of outright invasion, sometimes followed by colonization, whereafter invading-country companies are given market access or ownership of key assets. ${ }^{6}$

\footnotetext{
${ }^{6}$ Historically, some companies have even taken a direct role in military campaigns and colonial man-
} 
Second, once a market is "opened", military intervention may be required to maintain trade and safeguard foreign investments (for several 19th century examples of British intervention motivated by such goals, see Lipson, 1985). The 1902-03 blockade of Venezuela by major European powers is illustrative. Venezuela had just emerged from a costly civil war and had accrued foreign debts on infrastructure investments - for example, German Krupp had built the great Venezuelan Railway - which the new regime under Cipriano Castro refused to honor. After Venezuela refuted diplomatic overtures, German and British naval forces implemented a blockade. The conflict ended with an agreement where Venezuelan custom duties would pay off foreign debts, with preferential treatment afforded debts from the blockade-initiating countries.

Third, business elites may sometimes even increase $E(r)$, and reap excessive profits, from supplying weapons or other inputs needed for the war effort. One well-known example is the fortunes of major German industrial companies such as Krupp (Manchester, 2017).

Fourth, direct losses from war can sometimes be relatively low for business elites, especially for wars fought far from the country's territory with low risk of factories or vital infrastructure being destroyed. Business elites are unlikely to be engaged in direct combat, as other groups such as peasants (in rural 19th century economies) or industrial workers (in urban 19th century economies) have populated armies. This reflects the assumption that, for business elites, expected losses mainly consists of monetary costs. The absence of large non-pecuniary costs makes it more likely that expected gains exceed expected costs.

In sum, business elites likely profit from certain international wars, giving them an incentive to push - or at least not constrain - leaders to initiate militarized disputes. Given the insights from economic theory, we expect such incentives to be stronger for business elites in capital-intensive countries and in countries with large-scale businesses engaging in increasing-returns-to-scale production. Also, the more capital scarce (higher rents), the more populous (larger export market), and the more natural-resource rich (lower production costs) the potential "target country" is, the stronger are the incentives to attack. Further, business elites will have strong incentives to wage wars that lead to or maintain colonization of

agement. The British East India Company was present in India from the 17th century, and pressured the British government, through the East Indian lobby, to further its interests. In 1757, the company defeated the Nawad of Bengal Siraj-ud-Daula at Plassey, installed Mir Jafar as a puppet ruler, and procured the right to extract revenue in 1765. From its center in (opium-producing) Bengal, and with an 115,000 man strong army, the company enforced monopsony power against Indian competitors and financed its trade with China (Findlay and O'Rourke, 2007). During 1813-1820, Lord Governor of Bengal, Lord Moria, expanded the company's control by defeating the Gurkhas of Nepal and destroying the Maratha Empire. The company retained a monopoly of trade to 1833 . 
an area, if this supports the monopoly situation of home-country companies. If revenues are very high, business elites may even have incentives to angle for war against potential "competitor" countries to prevent their businesses from "taking" shares from profitable foreign markets (following the notion of monopolistic capitalism causing geo-political conflict in Lenin, 1999).

Yet, this is only part of the picture. Wars may reduce $E(r)$ and affect $E(c)$ through various other channels, as highlighted by the above-reviewed "capitalist peace" arguments. ${ }^{7}$ Such accounts predict that business elites are averse to war when profits depend on existing economic networks that create interdependence through foreign trade and investments. War may interrupt such networks. Hence, business elites reliant on international trade should be averse to wars with countries that are already major trading partners (Russett and Oneal, 2001). ${ }^{8}$ Insofar as war interrupts trade between warring parties (Anderton and Carter, 2001), costs include reduced imports of key inputs to production (increasing $E(c)$ ) and reduced exports (reducing $E(r)$ ). War might also put any foreign investments in the opposing country at risk of destruction or expropriation. Hence, business elites may have incentives to constrain leaders from starting wars, especially wars against countries that disrupt major trade flows or put existing foreign investments at risk.

In sum, we have considered two seemingly contrasting perspectives on how business elites, when they have political leverage, will influence the likelihood of international conflict. The "imperialist perspective" emphasizes the benefits to business elites from warfare, whereas the "capitalist peace" perspective emphasizes that warfare may hurt business. Still, these perspectives highlight very different types of changes to the costs and revenues of domestic businesses, which are likely to be more/less prevalent depending on contextual factors.

One key contextual factor is whether the target state is already integrated in the world economy, or is signaling willingness that it will integrate in the near future. If so, business elites in potential initiator states are more likely to conduct trade or have investments in the target state, thereby increasing the relevance of the pacifying capitalist peace mechanisms. This scenario, we surmise, is more likely if the target state's regime is (also) supported by business elites, and in particular where the target and the initiator are already major trading

\footnotetext{
${ }^{7}$ In addition, large-scale warfare increases wages by diverting workers to the war effort and squeezing labor supply. Wars are also costly for the state, and need to be financed, partly through taxes. Yet, while taxes (on business) may increase with interstate conflict many wars have, historically, been financed through loans and issuing of government bonds.

${ }^{8}$ Business elites could even disfavor war more generally since it creates uncertainty and market slowdowns that hurts business and trade across the board. On this account, elites whose profits rely on financial markets should be averse to war (Gartzke, Nordstrom and Boehmer, 2011).
} 
partners. Notably, if business elites are not part of the support coalitions, and countries are major trading partners, the economic costs of war may be less important for the political decision-making calculus. Since we assume that business elites are mainly interested in maximizing expected profits, and will use any political leverage that they may have to further this end, whether business elites are agents of war or peace will likely depend on whether the potential target state's regime is supported by business elites and whether it is already a major trading partner.

We bring the following empirical implications to the data:

First, we test the hypothesis that regimes supported by business elites are, overall, more likely to initiate a conflict than regimes without business elites in the support coalition. This expectation stems from the multiple possible targets where business elites can expand markets and expropriate foreign resources during the 1789-2018 time-span under study.

Second, we anticipate a very different relationship when potential target states are "business friendly" and already engage in, or signal that they will engage in, international trade and investment. Domestic business elites should have weaker incentives to pick fights with like-minded trading states than with closed economies. Specifically, we expect that regimes supported by business elites are less inclined to fight other regimes supported by business elites.

We also test an implication concerning conditional effects discussed above: The pacifying effect of belonging to a business-business dyad should be more pronounced in dyads with high pre-existing levels of trade. We expand on this additional implication, as well as possible scope conditions of the argument pertaining to, e.g., historical period under study, after our main tests.

\section{Data and research design}

We present and discuss the data and operationalization, first, for our key independent variable and, second, for our dependent variable. Thereafter, we introduce the control variables and benchmark specification.

\subsection{Regime support groups}

While previous contributions have used structural factors to proxy for the economic preferences of regimes and their supporters (see Schneider, 2017), we employ new data on regime

support groups (see Knutsen et al., 2019) that allow us to more directly capture whether or 
not business elites are important political actors. These data, which are embedded in v.9 of the V-Dem dataset (Coppedge, Gerring, Knutsen, Lindberg, Teorell, Altman, Bernhard, Fish, Glynn, Hicken, Lührmann, Marquardt, McMann, Pemstein, Seim, Sigman, Skaaning, Staton, Wilson, Cornell, Gastaldi, Gjerlow, Ilchenko, Krusell, Maxwell, Mechkova, Medzihorsky, Pernes, von Romer, Stepanova, Sundstrom, Tzelgov, Wang, Wig and Ziblatt, 2019), cover almost 200 countries with maximum time series running from 1789-2018 and modal time series from 1900-2018. Our measures on regime support groups are coded by country experts, mostly political historians, political scientists or other social scientists who have studied the political system of the country in question (for details on expert recruitment and methodology, see Knutsen et al., 2019; Coppedge et al., 2020).

The experts were presented with a 14-category scheme of potential support groups. In addition to business elites, the scheme includes other socio-economic groups such as Agrarian elites, Urban middle classes, and Industrial workers, and key groups characterized by their place in the traditional social hierarchy or state apparatus, including The aristocracy, Party elites, and The military. This scheme is used for a multiple selection variable and a singleselection variable (most important group). The multiple-selection version reads: "Which groups does the current political regime rely on in order to maintain power?", where groups to be coded are "supportive of the regime, and, if it/they were to retract support would substantially increase the chance that the regime would lose power". To ensure consistency in the understanding of the 'regime' concept and the particular regimes' identities, all experts were presented with detailed concept clarification plus pre-coded dates and name of each regime (see Djuve, Knutsen and Wig, 2020). Experts could then code support groups as time-varying features, also within regimes, down to the date level.

Our main measure is a dummy scored 1 for regimes that are supported by business elites, and 0 otherwise. This dummy draws on the multiple selection question on support groups. (We use the most important group question for robustness tests). Multiple experts code support groups for each country-year, and the original V-Dem variable is continuous, taking the mean of the experts' scores for presence (1) or absence (0) of business elites in the coalition. For our main measure, we require that half or more of all experts, for a given country-year, agree that business elites are a support group to code it as a "businesssupported regime". That is, our main dummy measure is scored 1 if the continuous, original $\mathrm{V}$-Dem measure is $\geq 0.5$ and 0 if the original measure is $<0.5$.

Requiring that half of the expert coders agree on business elites being part of the support coalition sets a fairly high threshold. Yet, it also allows for the coding of a business regime 
even if, say, one deviant expert coder out of four has a different understanding of the historical record. This should increase reliability relative to a very strict threshold requiring that all experts should agree for coding the regime as a business-supported regime. Still, we do test such a restrictive measure, and our main results are robust. We also run models with the original, continuous V-Dem measure, which allow us to distinguish situations where business elites are clearly not part of the support coalition from cases where this is more unclear even to country experts (which could indicate that the group has some influence over the regime). Further, we test specifications where we normalize business group participation by the total number of groups in the support coalition to account for less influence in larger coalitions. The count of support groups is done by aggregating across similar dummies as the one constructed for business elites, for all 14 group categories. We note that while business elites is a fairly common support group, it is not among the most common ones in our samples. Rather, military, party elites and foreign governments have been the three most common support groups, globally, during the past 200 years.

Figure 1 illustrates that there is ample historical variation in business elites' inclusion in support coalitions. The figure shows the share of countries in which business elites participated in the regime support coalition in a given year. The participation of business elites increased quite rapidly from the mid-1800s to 1900. The marked drop in 1900 reflects that the sample of countries covered in V-Dem increases in 1900, notably with the inclusion of numerous African and Asian colonies. Thus, this drop is driven by the new polities entering the sample less often having business elites in the support coalition. Further, the share of countries with business elites in the support coalition declined during the early 20th century, but after WWII it has increased steadily. In 2018, more than half of all support coalitions included business elites.

Figure 2 shows how the historical development in business-supported regimes has varied across geographical regions. For instance, the share of regimes supported by business elites increased rapidly in Western Europe and North America during the 1800s, but has been more stable during the 1900s. Eastern Europe had a very low share of business-supported regimes for most of modern history, but this changed after the dissolution of the Soviet Empire. In Latin America and the Caribbean, regimes supported by business elites have been relatively common in both the 19th and 20th centuries, and this is currently the region with the highest share of business-supported regimes. The share of regimes supported by business elites has been and is still comparatively low in MENA and in Sub-Saharan Africa. Business elites' involvement in regimes also varies within countries over time, as illustrated 
Figure 1: Business elites in regime coalitions, globally. 1789-2018

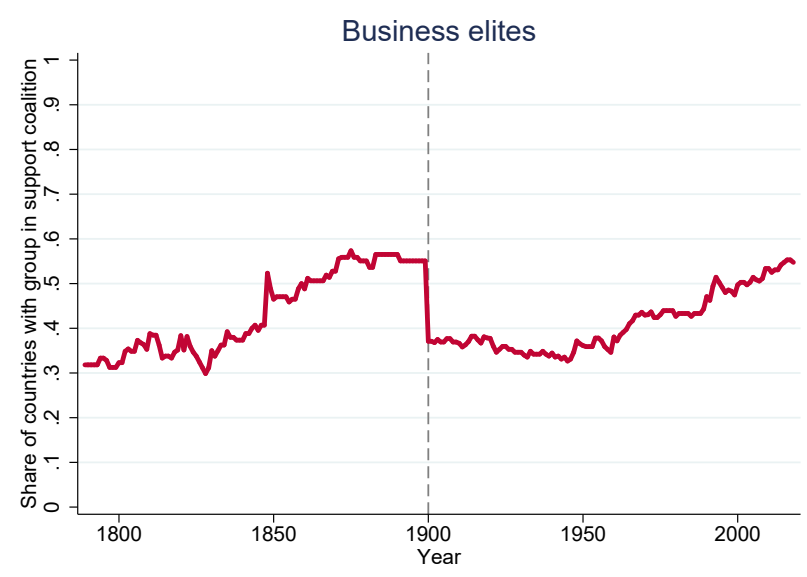

Share of global regimes with business elites participating in the support coalition. A regime is considered as having business elites in its support coalition if the original measures from V-Dem on social groups' inclusion in support coalitions is coded as above or equal to 0.5 . This corresponds to half or more of all experts agree that a certain social group is included in a support coalition.

by Figure 3, which shows the historical development in a selection of countries.

\subsection{Conflict}

For our main dependent variable, we use data on onset of Militarized Interstate Disputes (MID) that yields at least one casualty, drawn from the Correlates of War (COW) project (Sarkees and Wayman, 2010). MIDs are operationalized as "conflicts in which one or more states threaten, display, or use force against one or more other states". 9 The main reason for analyzing MIDs rather than full-blown interstate wars - conflict incidents between states that reach a 1000-casualty threshold - is that a MIDs-based measure captures additional, theoretically important information. As our argument and empirical illustrations make clear, we are theoretically interested in hostile actions that often stop short of full-blown wars, such as "gunboat diplomacy" against weak opponents. Indeed, MIDs are events that come from actions that ex ante carried a risk of escalating to war; escalation to full-blown wars will often result from bargaining failures and random factors that are in "the error term" (Gartzke, 1999), and war is not necessarily a premeditated outcome (see also Braumoeller, 2019). Since our argument focuses on ex ante derived expected costs and gains of conflict, there is a clear theoretical relevance of capturing the initiation of interstate conflicts, even if these, ex post, turn out not to give numerous casualties (e.g. because the target is quickly defeated or

\footnotetext{
${ }^{9}$ See http : //cow.dss.ucdavis.edu/data - sets/MIDs.
} 
Figure 2: Business elites in regime coalitions, by regions. 1789-2018
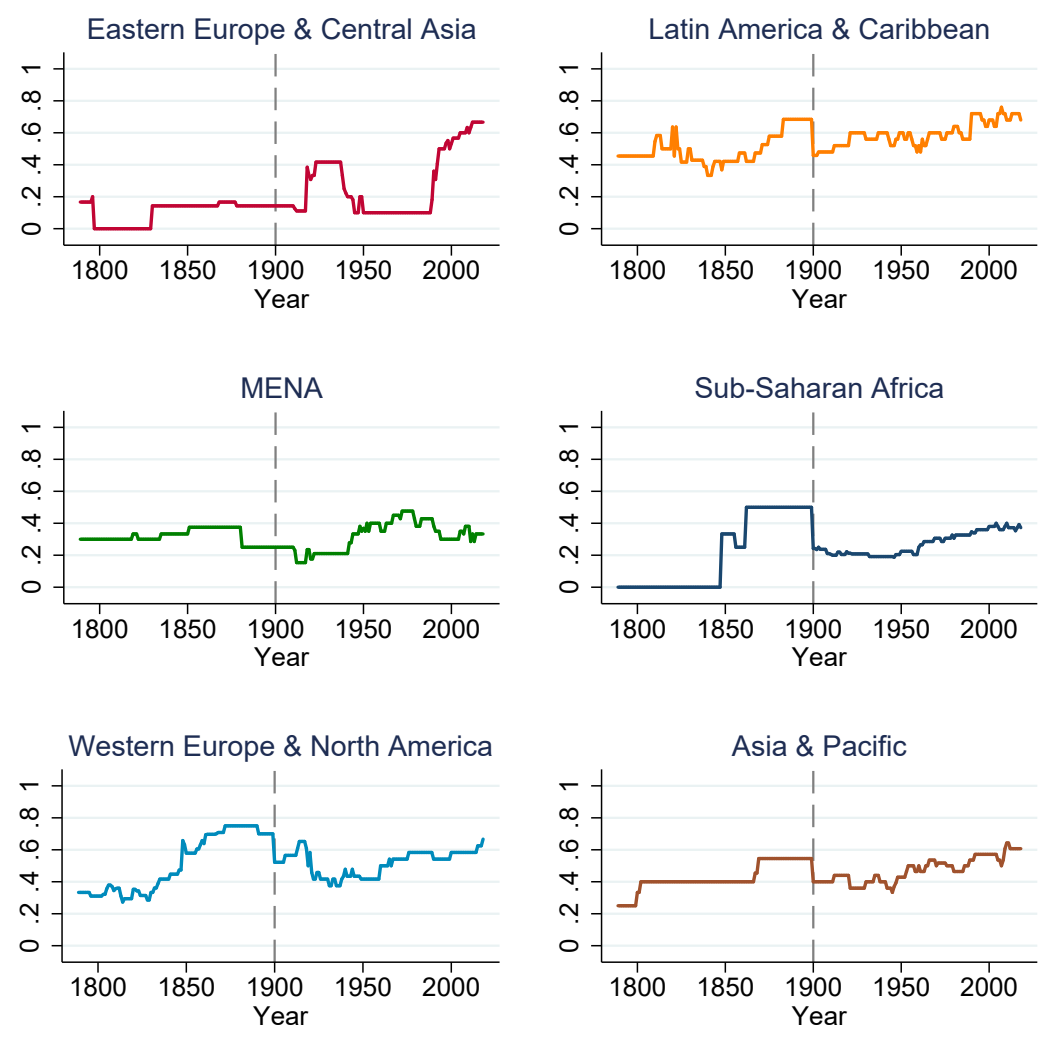

Share of regimes in each region with business elites participating in the support coalition. A regime is considered as having business elites in its support coalition if the original measures from V-Dem on social groups' inclusion in support coalitions is coded as above or equal to 0.5. This corresponds to half or more of all experts agree that a certain social group is included in a support coalition.

backed down when facing credible displays of force). Finally, there are many more MIDs than full-blown wars, and the additional variation means that we obtain much more efficient estimates, and can conduct more stringent control strategies and analysis of theoretically relevant sub-samples, when using MIDs.

\subsection{Empirical specification and core control variables}

From our theoretical argument, we derived both monadic expectations - on business elites in the support coalition in the potential conflict-initiating country $i$ increasing overall conflict risk - and dyadic ones - concerning the pacifying effect of simultaneously having business elites in the support coalitions in country $i$ and the potential target country $j$. Given the dyadic expectation, and since our theoretical argument relates to incentives for initiating 
Figure 3: Business elites in regime coalitions, selected countries. 1789-2018
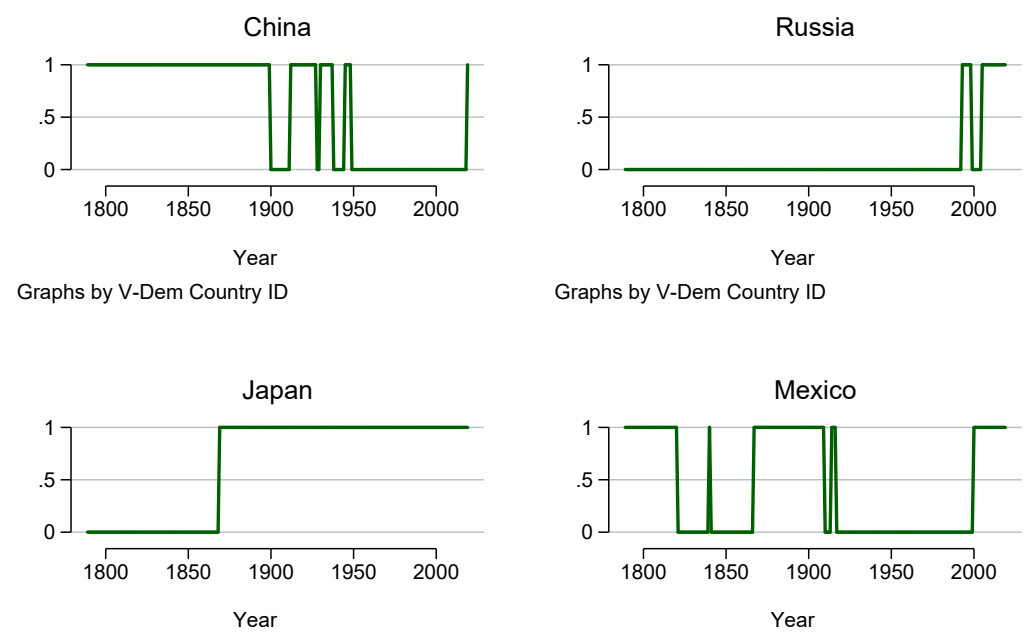

Graphs by V-Dem Country ID

Graphs by V-Dem Country ID
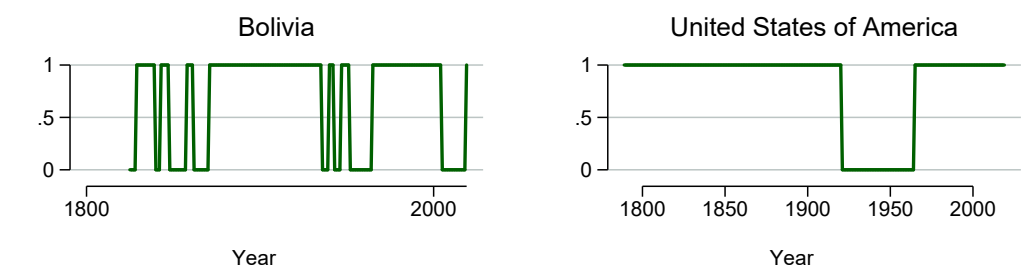

Graphs by V-Dem Country ID

Graphs by V-Dem Country ID
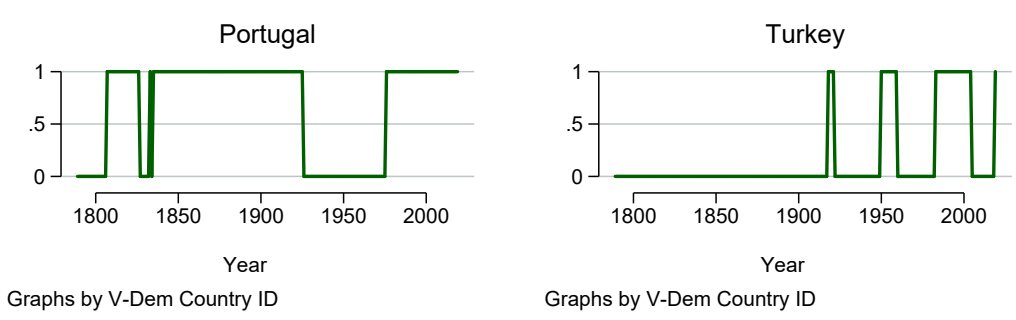

A regime is considered as having business elites in its support coalition if the original measures from V-Dem on social groups' inclusion in support coalitions is coded as above or equal to 0.5. This corresponds to half or more of all experts agree that a certain social group is included in a support coalition.

conflict, we test our hypothesis on directed dyads where the outcome is MID-initiation (see Reiter and Stam, 2003). A directed dyad is a country-pair, $i$ and $j$, where $i$ is a potential initiator and $j$ a potential target. All countries appear as both $i$ and $j$; for each dyad, there are two directed dyads. If country $i$ starts a conflict with country $j$, we register " 1 " in the directed dyad $i-j$, but 0 in $j-i$. Each variable that is measured for the initiator 
(target) appears with the subscript $i(j)$. The unit of analysis is thus directed dyad-years, and we estimate logit models capturing the risk of initiating a fatal MID in a given year, with standard errors clustered on dyads.

One key challenge is that several confounders could drive selection both into the category of "business-elite regimes" and affect conflict behavior. Absent relevant natural experiments, we mainly employ a selection-on-observables strategy where we account for different observable factors that could influence both likelihood of having business elites in the support coalition and conflict initiation. Our benchmark logit regressions therefore includes several covariates, most of which are typical controls from the interstate conflict literature, measured separately for countries $i$ and $j$. First, we include GDP per capita and population. Both variables are log-transformed, and we use the extensive time series with imputed estimates from Fariss et al. (2017). The authors arrive at these imputed estimates via a dynamic latent trait model run on various GDP and population datasets, and we use their estimates benchmarked in the Maddison project time series (Bolt and van Zanden, 2013). Second, we account for states' material capabilities, measured as CINC scores from COW; economically developed and powerful countries may more often have business-elites as part of their support coalition. At the dyad-level, we include contiguity (i.e., shared border) and distance between the two countries. Neighboring and proximate countries may, for various reasons, be more likely to have similar support coalitions and rates of conflict.

Our benchmark also includes linear, squared, and cubed terms for peace years in the dyad to capture conflict history. While we would have liked to include year- and dyad-fixed effects in all models to more fully safeguard against omitted confounders, there is simply not enough variation in the data to support the inclusion of such dummies simultaneously. We do estimate some models with dyad-fixed effects, and adding these dummies reduce our effective $\mathrm{N}$ to less than $15 \%$ of our original sample (on the issue of country-/dyad-fixed effects and reduced efficiency in IR research, see Beck and Katz, 2001). Thus, we rather include region- and decade-fixed effects in our benchmark to ensure relatively efficient estimation while capture temporally stable geographic confounders and any time trends.

In some models, we also control for dyadic democracy to account for our results potentially reflecting a "democratic peace" effect; democracies could be more likely to include business elites in their support coalitions and are less likely to fight each other. We use VDem's Polyarchy measure of electoral democracy (Teorell et al., 2019), and follow standard practice in the democratic peace literature by measuring only the lowest democracy score in the dyad (see Goertz, 2006). Yet, we leave this control out of our benchmark; certain social 
groups, such as urban middle classes (Moore, 1966) or industrial workers (Rueschemeyer, Stephens and Stephens, 1992), are likely to influence the regime in a more democratic direction if they partake in support coalitions, for instance by demanding stronger civil liberties protection or franchise extensions. Thus, controlling for democracy could be very well yield post-treatment bias when investigating the effect of a particular support group such as business elites.

In yet other specifications, we control for numerous additional factors, including measures of state capacity and other institutional features, to assess robustness. These additional tests are detailed below.

\section{$5 \quad$ Empirical analysis}

\subsection{Main results}

Table 1 displays our benchmark results, pertaining to our two main expectations. Model 1.1 estimates a logit model of MID initiation with errors clustered on dyads, region- and decadefixed effects, but only including the benchmark covariates that we believe are most likely to be "pre-treatment", namely material capabilities, GDP per capita, population, distance, and contiguity. All covariates are lagged by 1 year and non-dyadic variables (e.g., population) are measured both for the potential initiator and target. Model 1.2 adds covariates that might confound the relationship, but could also plausibly be post-treatment. These are VDem's measures of size of the support coalitions and the number of groups in the coalitions (both for initiators and targets), and joint (dyadic) democracy. Regardless of whether we add these potential post-treatment covariates, we find the expected relationships. Businesssupported regimes appear more likely to initiate conflict, everything else equal, but the estimated interaction term suggests that they are less likely to do so against other businesselite regimes. Notably, results from Model 1.2 suggest that these patterns are not driven by business elites having different probabilities of entering the support coalition in more and less democratic regimes or in larger or smaller support coalitions, as we control for these features in Model 1.2. Taken together, these results provide preliminary evidence for our argument.

To facilitate interpretation, we calculate the predicted probabilities of fatal MID initiation under different scenarios, drawing on the estimates from Model 1.2. Figure 4 shows predicted risks of MID initiation in a given year, when all other covariates are kept at their mean values,

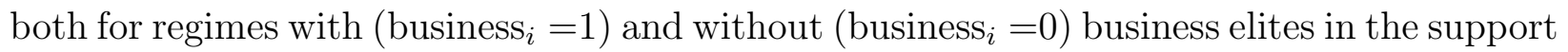


Table 1: Directed dyadic logit models of fatal MID initiation: Evaluating the role of business elites

\begin{tabular}{|c|c|c|c|c|}
\hline \multirow{3}{*}{$\begin{array}{l}\text { Measure } \\
\text { Business elites i }\end{array}$} & 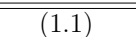 & (1.2) & 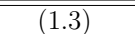 & " (1.4) \\
\hline & \multicolumn{2}{|c|}{ Presence in coalition } & \multicolumn{2}{|c|}{ Relative share } \\
\hline & $\begin{array}{c}0.361^{* * *} \\
(3.35)\end{array}$ & $\begin{array}{c}0.413^{* * *} \\
(3.50)\end{array}$ & $\begin{array}{c}7.229^{* * *} \\
(4.32)\end{array}$ & $\begin{array}{c}8.243^{* * *} \\
(4.53)\end{array}$ \\
\hline Business elites i & $\begin{array}{c}0.420^{* * *} \\
(3.62)\end{array}$ & $\begin{array}{c}0.418^{* *} \\
(3.27)\end{array}$ & $\begin{array}{c}8.933^{* * *} \\
(5.33)\end{array}$ & $\begin{array}{c}9.417^{* * *} \\
(5.10)\end{array}$ \\
\hline Business elites (dyad) & $\begin{array}{c}-0.498^{* *} \\
(-3.03)\end{array}$ & $\begin{array}{c}-0.462^{* *} \\
(-2.88)\end{array}$ & $\begin{array}{c}-125.1^{* * *} \\
(-3.81)\end{array}$ & $\begin{array}{c}-119.2^{* * *} \\
(-3.77)\end{array}$ \\
\hline $\operatorname{Ln~GDP}_{i}$ & $\begin{array}{c}0.158^{* *} \\
(2.83)\end{array}$ & $\begin{array}{c}0.182^{* *} \\
(3.08)\end{array}$ & $\begin{array}{c}0.133^{*} \\
(2.35)\end{array}$ & $\begin{array}{l}0.148^{*} \\
(2.53)\end{array}$ \\
\hline $\operatorname{Ln~GDP}_{j}$ & $\begin{array}{c}0.158^{* *} \\
(3.01)\end{array}$ & $\begin{array}{c}0.232 * * * \\
(3.93)\end{array}$ & $\begin{array}{l}0.129^{*} \\
(2.53)\end{array}$ & $\begin{array}{c}0.194^{* * *} \\
(3.42)\end{array}$ \\
\hline Ln $\mathrm{Pop}_{i}$ & $\begin{array}{c}0.171^{* *} \\
(3.00)\end{array}$ & $\begin{array}{c}0.146^{*} \\
(2.44)\end{array}$ & $\begin{array}{c}0.193^{* * *} \\
(3.37)\end{array}$ & $\begin{array}{c}0.175^{* *} \\
(2.92)\end{array}$ \\
\hline Ln $\operatorname{Pop}_{j}$ & $\begin{array}{c}0.0799 \\
(1.43)\end{array}$ & $\begin{array}{c}0.0145 \\
(0.24)\end{array}$ & $\begin{array}{l}0.102 \\
(1.82)\end{array}$ & $\begin{array}{c}0.0435 \\
(0.72)\end{array}$ \\
\hline $\mathrm{CINC}_{i}$ & $\begin{array}{c}4.977^{* * *} * \\
(4.65)\end{array}$ & $\begin{array}{c}4.648^{* * *} \\
(4.18)\end{array}$ & $\begin{array}{c}5.178^{* * *} \\
(4.82)\end{array}$ & $\begin{array}{c}4.922^{* * * *} \\
(4.36)\end{array}$ \\
\hline $\mathrm{CINC}_{j}$ & $\begin{array}{l}2.302 \\
(1.85)\end{array}$ & $\begin{array}{l}1.663 \\
(1.32)\end{array}$ & $\begin{array}{c}2.511^{*} \\
(2.01)\end{array}$ & $\begin{array}{l}1.932 \\
(1.52)\end{array}$ \\
\hline Contiguity & $\begin{array}{r}-0.0437 \\
(-0.31)\end{array}$ & $\begin{array}{c}-0.0200 \\
(-0.15)\end{array}$ & $\begin{array}{c}-0.0266 \\
(-0.20)\end{array}$ & $\begin{array}{c}-0.00331 \\
(-0.03)\end{array}$ \\
\hline Ln distance & $\begin{array}{c}-0.148^{* * *} \\
(-3.54)\end{array}$ & $\begin{array}{c}-0.155^{* * *} \\
(-3.99)\end{array}$ & $\begin{array}{c}-0.156^{* * *} \\
(-3.97)\end{array}$ & $\begin{array}{c}-0.164^{* * * *} \\
(-4.46)\end{array}$ \\
\hline Joint democracy (dyad) & & $\begin{array}{c}-1.336^{* * *} \\
(-5.23)\end{array}$ & & $\begin{array}{c}-1.378^{* * *} \\
(-5.39)\end{array}$ \\
\hline Groups in coalition $_{i}$ & & $\begin{array}{c}-0.0000475 \\
(-0.00)\end{array}$ & & $\begin{array}{c}-0.0273 \\
(-0.36)\end{array}$ \\
\hline Groups in coalition $_{j}$ & & $\begin{array}{c}0.0773 \\
(1.14)\end{array}$ & & $\begin{array}{l}0.0175 \\
(0.25)\end{array}$ \\
\hline Size of support coalition $i$ & & $\begin{array}{c}0.000359 \\
(0.01)\end{array}$ & & $\begin{array}{c}0.00665 \\
(0.14)\end{array}$ \\
\hline Size of support coalition ${ }_{j}$ & & $\begin{array}{c}-0.0203 \\
(-0.49)\end{array}$ & & $\begin{array}{l}-0.0145 \\
(-0.35)\end{array}$ \\
\hline Region-dummies & $\checkmark$ & $\checkmark$ & $\checkmark$ & $\checkmark$ \\
\hline Decade-dummies & $\checkmark$ & $\checkmark$ & $\checkmark$ & $\checkmark$ \\
\hline Duration terms & $\checkmark$ & $\checkmark$ & $\checkmark$ & $\checkmark$ \\
\hline $\mathrm{N}$ & $1,080,286$ & $1,037,428$ & $1,092,232$ & $1,049,278$ \\
\hline
\end{tabular}


Figure 4: Predicted probabilities of initiating fatal MID for different values of Business elites ${ }_{i}$, conditional on whether Business elites ${ }_{j}=0$ (left panel) or Business elites ${ }_{j}=1$ (right panel). Estimates are based on Model 1.2, and all other covariates are at their means.
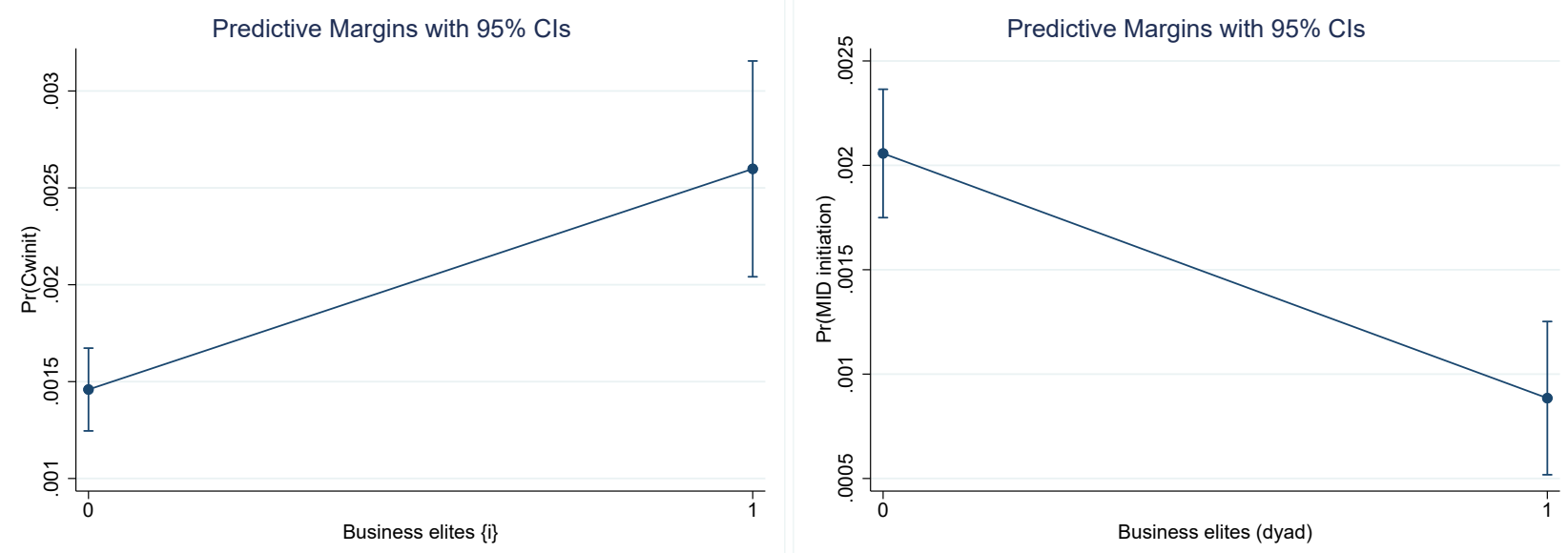

coalition. We also consider situations when the potential target does (business ${ }_{j}=1$; right panel) and does not have (business ${ }_{j}=0$; left panel) business elites in the support coalition. Business-supported regimes are considerably more likely to initiate MIDs than "non-business regimes" when the target country's regime is not supported by business elites; a non-business initiator has a .0015 probability of starting a conflict against a non-business target, while the corresponding number is .0026 when the initiator is a business-supported regime. The low estimated probabilities mainly reflect the rarity of conflict and the dyad-year data structure. Back-of-the envelope aggregations provide a better illustration of the results' substantive magnitude: In a world with 50 potential non-business targets (the number in 1913), there is a $13 \%$ probability that a business-supported regime will initiate at least one conflict against non-business targets in a year. If both regimes were non-business regimes, the corresponding risk is $7 \%$. This pattern supports our first expectation on the belligerence of business elites when conflict is anticipated to be profitable.

In sharp contrast, business-supported regimes are relatively less likely than non-business regimes to initiate conflicts against targets supported by business regimes. This follows our second expectation on business elites having pacific incentives once conflicts hurt existing trade relationships and foreign investments. For business-supported targets, the risk of a business-supported regime initiating conflict in a year is below .001, about half of the 
probability of a non-business regimes initiating conflict against a business target. According to these results, business-business dyads are the most peaceful ones, and a business regime is more than three times as likely to initiate conflict with a non-business regime than with another business-regime.

\subsection{Robustness tests}

We conducted various robustness tests to assess the sensitivity of our results to different measurement, sample, and model specification choices. We start by assessing sensitivity to how we measure business elite involvement in the support coalition. The rightmost columns in Table 1 replicate the benchmark specifications, but employ the discussed relative-share version of the measures. To recapitulate, these measures divide the business elite dummy used in the above analysis by the number of groups that partook in the support coalition that year, both for $i$ and $j$. The results suggest that when business groups play a more prominent role in the support coalition, a country is more likely to attack countries where business groups play a lesser role, and less likely to attack countries where business elites play a larger role. In Appendix Table A.5, we show that our main results are robust to using the original, continuous, version of the business support group measure, which is, e.g., scored 0.75 if three of four country-experts rate business elites as part of the support coalition. Results for the monadic expectation on business-supported regimes being more belligerent are also robust to using a stricter scoring of the dummy variable on support group presence, requiring that all V-Dem experts agree that business elites were in coalition that year. However, results for the dyadic expectation on more pacific business-business dyads are less clear when using this measure. Finally, we probed V-Dem's 'most important support group' measure, only capturing cases where a plurality of experts coders consider business elites to be the most important group in the support coalition. The first expectation on belligerent business elites is once again supported, while results are weaker for the second expectation on pacific business-business dyads.

Next, we tested sensitivity of our results to the inclusion of particular observations. More specifically, we exclude WWI and WWII, by dropping the years 1914-1918 and 1939-1945 from the dataset, and re-estimate our core models. We do so to ensure that results do not hinge on these historically unique conflicts involving multiple countries linked through alliances. Our results remain similar when excluding these cases (see Table A.2).

The results above offer at least two interpretations; they could reflect causal processes tying regime-support group identity to conflict, or they could stem from omitted factors that 
condition both identity and conflict. We have no surefire way to clearly adjudicate between these two interpretations. Still, we conduct several additional tests to further assess the plausibility of a causal interpretation of the results, in line with our argument.

First, we conduct the perhaps most demanding test by controlling for dyad-fixed effects. Accounting for such effects on conflict means controlling for all confounders that are relatively time-invariant and pertain to particular initiator and target countries, and to their bilateral relationship. This test is demanding in the sense that it likely yields large standard errors and related likelihood of conducting Type II errors, given the limited number of conflicts and relevant variation in the data (despite our long time series). Nonetheless, we estimated a version of the logit model 1.2, but with dyad-fixed effects (Table A.1). When doing so, we lose more than $90 \%$ of our observations, due to no over-time variation in support groups and conflict. We also estimated a linear probability (OLS) model with dyad-fixed effects, which keeps the observations pruned by the logit-FE model. Perhaps unsurprisingly, the models with dyad-fixed effects yield weaker results. For example, the main terms for business elites are insignificant, and even change signs. Hence, the support for our first expectation is not completely robust, despite the strong relationship in the models without dyad-fixed effects. Nonetheless, the interaction term remains sizeable and highly significant even when adding dyad-fixed effects, suggesting that dyads become more peaceful once they obtain business elites in the support coalition of both countries' regimes. Moreover, the three business-terms are jointly significant in the different dyad-fixed effects models.

Next, we perform sensitivity analyses where we use information about selection on observable factors - i.e., we gauge how much estimates change when we include the measured confounders - as a guide to potential selection on unobservables. Specifically, we use the framework and software developed in Oster (2019), which adjusts the estimated coefficient under different scenarios of potential omitted variable bias. Several parameters are used to construct different scenarios. First, we make assumptions about the proportionality of selection on observables and unobservables. If we assume that unobservables (in a hypothetical scenario) move the coefficient as much as the (inclusion of) observables, then we have proportional selection, parametrized by $\delta=1$. Second, we make assumptions about the explained variance (in the treatment and outcome) that the unobservables can account for. We follow convention and parametrize this variance in terms of factors of the explained variance (e.g., twice the size of $R^{2}$ ) of the model with covariates. Given these assumptions, we can calculate the adjusted treatment effect under different omitted-variable scenarios. If our main result is retained in plausible scenarios, this should strengthen the belief that our 
Table 2: Sensitivity to omitted confounders

\begin{tabular}{|c|c|c|c|c|c|c|}
\hline \multirow[b]{3}{*}{$R^{2}$ from the unobserved confounder } & (2.1) & "(2.2) & $20(2.3)$ & $\begin{array}{ll}(2.4) \\
\end{array}$ & "(2.5) & $20(2.6)$ \\
\hline & \multicolumn{3}{|c|}{ Benchmark controls } & \multicolumn{3}{|c|}{ Additional controls } \\
\hline & .04 & .10 & .20 & .04 & .10 & .20 \\
\hline Business elites $_{i}$ & $.2048^{* * *}$ & $1.256^{* * *}$ & $3.011^{* * *}$ & $.0657^{* * *}$ & $.637^{* * *}$ & $1.596^{* * *}$ \\
\hline & $(.040)$ & .173 & .457 & $(.013)$ & .059 & $(.130)$ \\
\hline Business elites $_{j}$ & $\begin{array}{l}.188^{* * *} \\
(.031)\end{array}$ & $\begin{array}{c}1.149^{* * *} \\
(15)\end{array}$ & $\begin{array}{c}2.75^{* * *} \\
(324)\end{array}$ & $\begin{array}{l}.078^{* * *} \\
(.0198)\end{array}$ & $\begin{array}{c}.783^{* * *} \\
(.080)\end{array}$ & $\begin{array}{c}1.96^{* * *} \\
(.184)\end{array}$ \\
\hline Business elites (dyad) & $\begin{array}{c}-.352^{* *} \\
(.051)\end{array}$ & $\begin{array}{c}-2.006^{* * *} \\
(.250)\end{array}$ & $\begin{array}{c}-4.767^{* * *} \\
(.645)\end{array}$ & $\begin{array}{l}-.332 \\
(.246)\end{array}$ & $\begin{array}{l}-3.529 \\
(1.836)\end{array}$ & $\begin{array}{c}-8.861^{* * *} \\
(3.214)\end{array}$ \\
\hline $\mathrm{N}$ & $1,049,278$ & $1,049,278$ & $1,049,278$ & 832,122 & 832,122 & 832,122 \\
\hline
\end{tabular}

Notes: ${ }^{*} p<0.05,{ }^{* *} p<0.01,{ }^{* * *} p<0.001$. $T$ statistics in parentheses. Linear Probability Models. Bootstrapped standard errors (100 iterations). Intercept and covariates omitted from table. All models assume proportional selection. Models 2.1-2.3 include all covariates from Model 1.2, Table 1. Models 2.4-2.6 add the following covariates: Alliance membership, IGO membership, foreign policy similarity, state fiscal capacity, remuneration of bureaucrats, state sovereignty over territory, judicial constraints on executive index, civil society participation index, women's empowerment index, and physical violence index.

main results can be given a causal interpretation.

Table 2 evaluates three different omitted-variable scenarios for two sets of models. ${ }^{10}$ These omitted variable scenarios assume proportional selection and omitted confounders explaining 2-10 times the variance $\left(R^{2}\right)$ explained by our model. The first set of models include all our benchmark controls from Table 1. The second set add covariates to increase information about selection on observables, including alliance membership (from COW) and membership of similar IGO's and foreign policy preference similarity, using the tau measure Signorino and Ritter (1999). Further, we add covariates from V-Dem capturing various institutional aspects that could correlate with business-elite presence in the support coalition and influence conflict behavior. Three variables capture aspects of state capacity, namely state fiscal capacity, remuneration of bureaucrats, and state sovereignty over territory. We also include V-Dem's judicial constraints on the executive index, civil society participation index, women's empowerment index, and physical violence index (capturing internal repression and civil strife). We add these measures for both $i$ and $j$, yielding 14 new covariates from $\mathrm{V}$ Dem. Altogether, the new covariates account for a host of international-political, foreign policy and domestic-institutional features that may confound the relationship of interest.

Table 2 shows that the estimated coefficients for business elites actually turn stronger as we simulate an omitted confounder (vector) that explains more of the variance than the current model, assuming that selection from unobservables is proportional to selection from observables. This assumption seems plausible in light of results being similar when we add all

\footnotetext{
${ }^{10}$ These are linear probability (OLS) models, since there is no option for logit models in the software package. This should presumably not systematically affect the inferences we draw, which are primarily about the differences in coefficients between different control-variable sets.
} 
the new confounders that were not included in the original analysis: They produce selection in the same direction as the selection induced by our baseline controls, suggesting that the main selection bias issues with our business elite measures are ones that actually make our results stronger once corrected for. Our main result therefore seems quite robust to omitting relevant variables.

\subsection{Additional implications and scope conditions}

We also conducted several tests that address additional implications and potential scope conditions of our argument. Some of these tests are reported in Table 3, and others in the appendix. First, we split our sample between the pre- and post-WWI eras. Several historical examples that we discussed above, such as the ones on gunboat diplomacy, come from the 19 th and early 20th centuries. Hence, we suspected that our results might only hold for this period. However, when rerunning our benchmark on the pre- (Model 3.1) and post-1919 period (3.2), results are actually stronger in the post-1919 era. Notably, coefficient precision is higher in the later period, which probably reflects the increased number of countries and MIDs in the post-WWI era.

In Appendix Table A.4, we also test whether the discussed patterns depend on the majorminor power status of the countries in the dyad. We use COW data for identifying major and minor powers, and split the sample between major-major, major-minor, minor-major, and minor-minor dyads. This analysis reveals that our results, both concerning the belligerent effect of having business elites in the support coalition and the pacifying effect of businessbusiness dyads, are strongest when both the initiator and target are major powers. However, we also find strong indications of the first expectation (belligerent business elites) when the initiator is a major power and the target a minor power. Having business elites in the support coalition seems to drive the conflict behavior of major powers. We do not find support for our expectations when the initiator is a minor power.

Next, we consider the role of trade, operationalized as the log of total imports and exports (measured in USD, using the "smoothed" version from Barbieri, Keshk and Pollins, 2009)) in the dyad. We expect to observe stronger pacifying effects, especially for business-business pairings, in dyads where trade is high, since high levels of trade should be in the (general) interests of most business elites and could be disrupted by armed conflict. Since our main business-business term is an interaction, we investigate this by splitting the sample on high and low trade, before estimating the core model on these split samples. We split on median level of total trade, classifying trade flows above (below) the median as "high" ("low"). 
Table 3: Directed dyadic logit models of fatal MID initiation: Evaluating the scope conditions and additional implications

\begin{tabular}{|c|c|c|c|c|c|}
\hline & $(3.1)$ & $(3.2)$ & $(3.3)$ & $(3.4)$ & $(3.5)$ \\
\hline Alteration & Pre-1919 & Post-1919 & Above median trade & Below median trade & Other group controls \\
\hline Business elites i & $\begin{array}{c}0.742^{* * *} \\
(3.81)\end{array}$ & $\begin{array}{l}0.221 \\
(1.73)\end{array}$ & $\begin{array}{c}0.434^{* * *} \\
(3.88)\end{array}$ & $\begin{array}{c}0.176 \\
(0.63)\end{array}$ & $\begin{array}{c}0.307^{*} \\
(2.57)\end{array}$ \\
\hline Business elites i & $\begin{array}{l}0.333 \\
(1.55)\end{array}$ & $\begin{array}{c}0.541^{* * *} \\
(4.16)\end{array}$ & $\begin{array}{c}0.440^{* * *} \\
(3.56)\end{array}$ & $\begin{array}{c}0.689^{* *} \\
(3.16)\end{array}$ & $\begin{array}{c}0.446^{* * *} \\
(3.79)\end{array}$ \\
\hline Business elites (dyad) & $\begin{array}{l}-0.590^{*} \\
(-2.33)\end{array}$ & $\begin{array}{c}-0.478^{*} \\
(-2.47)\end{array}$ & $\begin{array}{c}-0.426^{*} \\
(-2.51)\end{array}$ & $\begin{array}{l}-0.526 \\
(-1.28)\end{array}$ & $\begin{array}{c}-0.414^{*} \\
(-2.53)\end{array}$ \\
\hline Agrarian elites & & & & & $\begin{array}{c}-0.0221 \\
(-0.18)\end{array}$ \\
\hline Aristocracy & & & & & $\begin{array}{l}-0.0998 \\
(-0.67)\end{array}$ \\
\hline Party elites & & & & & $\begin{array}{r}-0.0990 \\
(-0.73)\end{array}$ \\
\hline Bureaucracy & & & & & $\begin{array}{l}-0.106 \\
(-0.75)\end{array}$ \\
\hline Military & & & & & $\begin{array}{l}0.103 \\
(0.80)\end{array}$ \\
\hline Ethnic group & & & & & $\begin{array}{l}0.303 \\
(1.61)\end{array}$ \\
\hline Religious group & & & & & $\begin{array}{l}0.199 \\
(1.12)\end{array}$ \\
\hline Local elites & & & & & $\begin{array}{l}-0.252 \\
(-1.56)\end{array}$ \\
\hline Industrial workers & & & & & $\begin{array}{c}-0.799^{* * *} \\
(-4.06)\end{array}$ \\
\hline Urban middle class & & & & & $\begin{array}{l}0.181 \\
(1.22)\end{array}$ \\
\hline Rural workers & & & & & $\begin{array}{c}0.532^{* *} \\
(3.13)\end{array}$ \\
\hline Rural middle class & & & & & $\begin{array}{l}0.135 \\
(0.71)\end{array}$ \\
\hline Benchmmark controls & $\checkmark$ & $\checkmark$ & $\checkmark$ & $\checkmark$ & $\checkmark$ \\
\hline Region-dummies & $\checkmark$ & $\checkmark$ & $\checkmark$ & $\checkmark$ & $\checkmark$ \\
\hline Decade-dummies & $\checkmark$ & $\checkmark$ & $\checkmark$ & $\checkmark$ & $\checkmark$ \\
\hline $\mathrm{N}$ & 103,395 & 962,818 & 708,608 & 360,512 & $1,069,416$ \\
\hline
\end{tabular}


Figure 5: Predicted probabilities for Business elites conditional on Business elites $_{j}$, in hightrade dyads
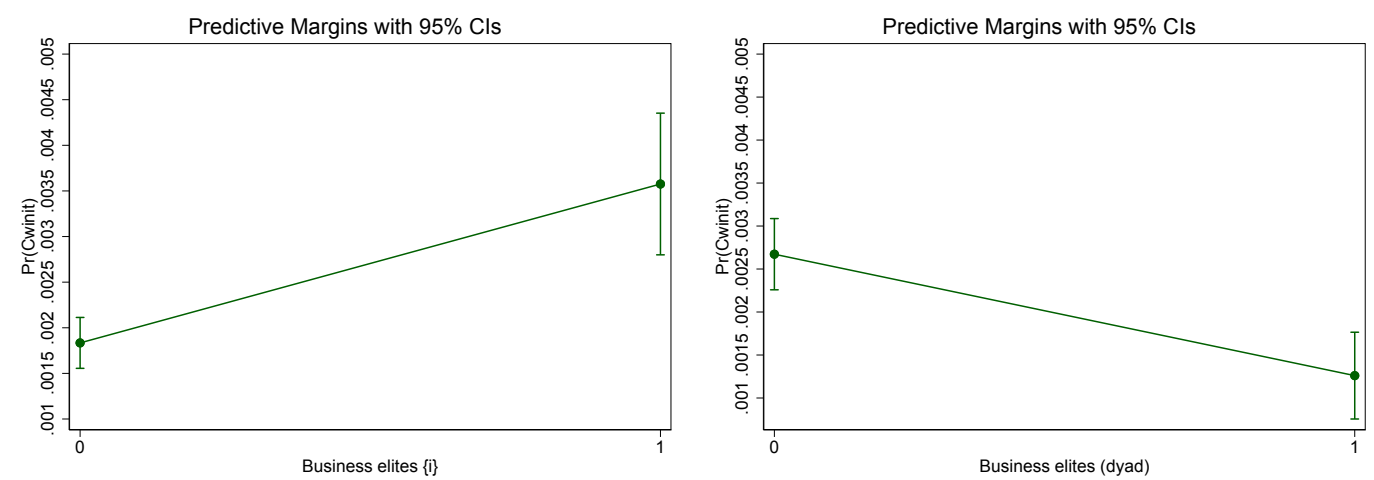

Figure 6: Predicted probabilities for Business elites ${ }_{i}$ conditional on Business elites ${ }_{j}$, in lowtrade dyads
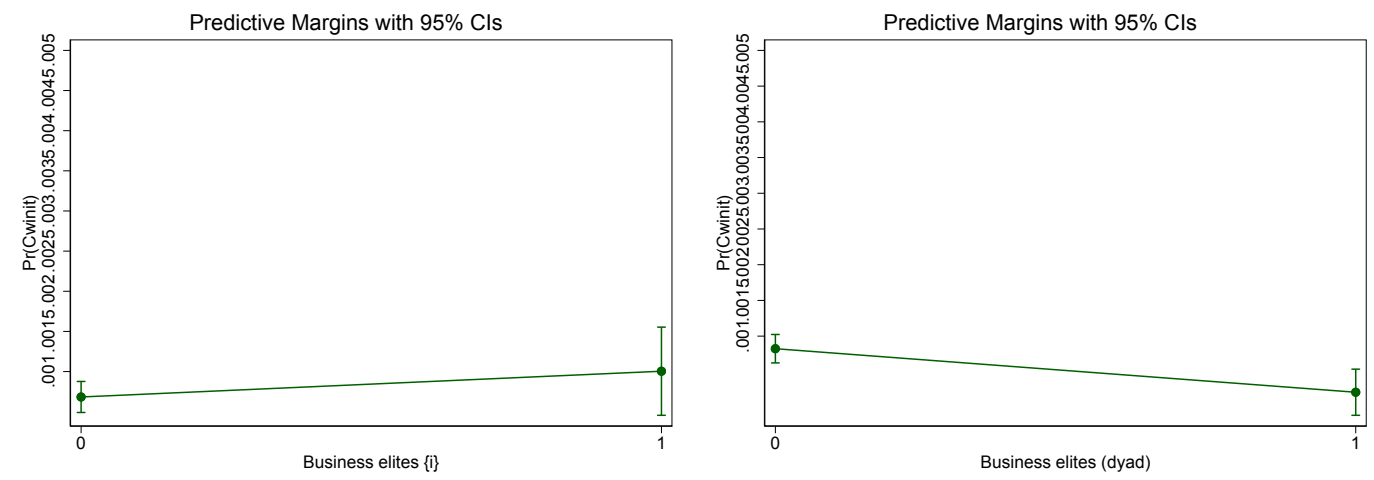

Marginal effect results are presented in Figures 5 and 6. In dyads with high trade (Figure 5 ), the business-business interaction on conflict is strongly negative, and precisely estimated, while it is much weaker for low-trade dyads (Figure 6). Business-supported regimes seem much less likely to fight other business-supported regimes when trade levels are high than when trade levels are low. However, and less in conformance with our expectations, we find a stronger effect of business regimes initiating conflict against non-business target countries when trade levels are high. These split sample results are more or less replicated when we consider exports or imports separately (Appendix A.3), rather than total trade.

Finally, Model 3.5, Table 3 reports a specification where we control for the presence of other groups in the regime's support coalition. The presence of business elites could be 
highly correlated with presence or absence of other particular groups, such as the aristocracy or urban middle classes, and these other groups may be driving conflict behavior rather than business elites. We thus control for presence of all other coded support groups in the initiator country. Our main results for business elites are not significantly altered by including these controls. There are interesting patterns also for other support groups. Notably, the presence of industrial workers in the support coalition significantly reduces the likelihood of conflict initiation. There are many potential reasons for this. For example, workers often bear the brunt of the casualties (in mass armies) of modern wars, and thus have strong incentives to avoid armed conflict. However, we leave it for future research to theorize and probe this empirical relationship more thoroughly.

\section{Conclusion}

In this paper, we have provided a framework for linking regime support group identity to international conflict behavior. More specifically, we synthesized classic "imperialist" and "capitalist peace" accounts that indicate various links between business elites and conflict behavior, and present a comprehensive argument on the context-dependent conflict preferences of business elites, and their consequent impact on conflict behavior when these elites enter regime support coalitions.

Empirically, we tested different expectations from this argument by linking a novel dataset on the social-group composition of support coalitions to conventional statistical models of conflict initiation from the IR literature. Given the comprehensive nature of our argument, our results speak to different theories of peace and war. First, some of our results corroborate the "capitalist peace" thesis, as regimes supported by business elites are less inclined to initiate militarized interstate disputes against other countries governed by business-supported regimes. The capitalist peace thesis would suggest that this relationship is due to the interdependent nature of the economic interests of these business elites residing in different countries. Indeed, the pattern is strengthened for pairs of countries with high levels of initial trade, further corroborating this interpretation.

Yet, our results do not suggest that business-supported regimes are less belligerent in all situations. In fact, the probability of initiating militarized interstate conflict is higher for business-supported regimes when only considering target countries where regimes are not supported by business elites. This result, we suggest, is more in line with traditional Marxist "imperialist" theories, such as the one proposed by Lenin, suggesting that business 
elites may encourage leaders to go to war in order to "open up" markets and thus allow their firms to reap additional profits. In sum, whether empowered business elites are a force for peace or conflict depends on the nature of the conflict, and more specifically the anticipated economic consequences of the conflict in question.

Our findings come with limitations that raise several questions for future research. First, our claims are based on correlational evidence, and can only support a tentative causal interpretation of the role of business elites in driving conflict. Future work, employing alternative designs and types of data, must be done to shore up a causal explanation. Second, future work may conduct a broader investigation into how the preferences of business elites translate into foreign policy outcomes, more generally, including outcomes such as trade, international cooperation, and diplomatic behavior. Third, we restricted our focus to business elites. Yet, our theoretical framework is general and can be extended to other groups, such as military elites, party elites, urban middle classes, or industrial workers, that may enter regime support coalition and have very different gains and costs from interstate conflicts. Importantly, the new V-Dem data on support coalitions allow researchers to test arguments and hypothesis concerning these alternative groups in a similar manner to what we have done here for business elites. Hence, our study provides a template for explicitly modeling and testing how variations in the social profile of regime support coalitions influence international conflict behavior, and potentially also behavior in other domains of international relations. 


\section{References}

Anderton, Charles H. and John R. Carter. 2001. "The Impact of War on Trade: An Interrupted Times-Series Study." Journal of Peace Research 38(4):445-457.

Angell, Norman. 1938. The Great Illusion - Now. Harmondsworth: Penguin.

Barbieri, Katherine, Omar M. G. Keshk and Brian Pollins. 2009. "Trading Data: Evaluating our Assumptions and Coding Rules." Conflict Management and Peace Science 26(5):471491.

Baum, Matthew A and Philip BK Potter. 2015. War and democratic constraint: How the public influences foreign policy. Princeton: Princeton University Press.

Beck, Nathaniel and Jonathan N. Katz. 2001. "Throwing out the Baby with the Bath Water: A Comment on Green, Kim, and Yoon." International Organization 55(2):187-195.

Bolt, J. and J. L. van Zanden. 2013. "The First Update of the Maddison Project; ReEstimating Growth Before 1820." Maddison Project Working Paper 4. .

Braumoeller, Bear F. 2019. Only the dead: the persistence of war in the modern age. Oxford: Oxford University Press.

Bueno de Mesquita, Bruce and Alastair Smith. 2012. "Domestic Explanations of International Relations." Annual Review of Political Science 15:161-181.

Bueno de Mesquita, Bruce, Alistair Smith, Randolph M. Siverson and James D. Morrow. 2003. The Logic of Political Survival. Cambridge, Ma.: MIT Press.

Bueno de Mesquita, Bruce, James D. Morrow, Randolph M. Siverson and Alastair Smith. 1999. "An Institutional Explanation of the Democratic Peace." American Political Science Review 93(4):791-807.

Bueno de Mesquita, Bruce, James D. Morrow, Randolph M. Siverson and Alastair Smith. 2004. "Testing Novel Implications from the Selectorate Theory of War." World Politics 56(3):363-368.

Choi, Seung-Whan. 2010. "Legislative constraints: A path to peace?" Journal of Conflict Resolution 54(3):438-470. 
Clark, Christopher. 2012. The Sleepwalkers: How Europe Went to War in 1914. London: Allen Lane.

Colgan, Jeff D. and Jessica L.P. Weeks. 2015. "Revolution, Personalist Dictatorships, and International Conflict." International Organization 69(1):163194.

Coppedge, Michael, John Gerring, Adam Glynn, Carl Henrik Knutsen, Staffan I. Lindberg, Daniel Pemstein, Brigitte Seim, Svend-Erik Skaaning and Jan Teorell. 2020. Varieties of Democracy: Measuring Two Centuries of Political Change. Cambridge: Cambridge University Press.

Coppedge, Michael, John Gerring, Carl Henrik Knutsen, Staffan I. Lindberg, Jan Teorell, David Altman, Michael Bernhard, Steven M. Fish, Adam Glynn, Allen Hicken, Anna Lührmann, Kyle L. Marquardt, Kelly McMann, Daniel Pemstein, Brigitte Seim, Rachel Sigman, Svend-Erik Skaaning, Jeffrey Staton, Steven Wilson, Agnes Cornell, Lisa Gastaldi, Haakon Gjerlow, Nina Ilchenko, Joshua Krusell, Laura Maxwell, Valeriya Mechkova, Juraj Medzihorsky, Josefine Pernes, Johannes von Romer, Natalia Stepanova, Aksel Sundstrom, Eitan Tzelgov, Yi-ting Wang, Tore Wig and Daniel Ziblatt. 2019. "V-Dem Country-Year Dataset v.9." Varieties of Democracy (V-Dem) Project.

Coppedge, Michael, John Gerring, Carl Henrik Knutsen, Staffan I Lindberg, Jan Teorell, Kyle L Marquardt, Juraj Medzihorsky, Daniel Pemstein, Josefine Pernes, Johannes von Römer et al. 2019. "V-dem methodology v9." Varieties of Democracy (V-Dem) Project.

Debs, Alexandre and Nuno P Monteiro. 2014. "Known unknowns: Power shifts, uncertainty, and war." International Organization 68(1):1-31.

Djuve, Vilde Lunnan, Carl Henrik Knutsen and Tore Wig. 2020. "Patterns of Regime Breakdown since the French Revolution." Comparative Political Studies 53(6):923-958.

Dunning, John H. 1993. Multinational enterprises and the global economy. Workingham: Addison Wesley.

Farcau, Bruce W. 2000. The Ten Cents War: Chile, Peru, and Bolivia in the War of the Pacific, 1879-1884. Praeger.

Fariss, Christopher J, Charles D Crabtree, Therese Anders, Zachary M Jones, Fridolin J Linder and Jonathan N Markowitz. 2017. "Latent Estimation of GDP, GDP per capita, and Population from Historic and Contemporary Sources." arXiv preprint arXiv:1706.01099 . 
Fearon, James D. 1994. "Domestic Political Audiences and the Escalation of International Disputes." American Political Science Review 88(3):577-592.

Feenstra, Robert C. 2003. Advanced International Trade: Theory and Evidence. Princeton: Princeton University Press.

Findlay, Ronald and Kevin H. O'Rourke. 2007. Power and Plenty: Trade, War, and the World Economy in the Second Millennium. Princeton: Princeton University Press.

Fischer, Fritz. 1967. Germany's aims in the First World War. New York: WW Norton.

Galtung, Johan. 1971. "A Structural Theory of Imperialism." Journal of Peace Research $8(2): 81-117$.

Gartzke, Erik. 1999. "War is in the error term." International Organization 53(3):597-587.

Gartzke, Erik. 2007. "The Capitalist Peace." American Journal of Political Science 51(1):166-191.

Gartzke, Erik, Timothy Nordstrom and Charles Boehmer. 2011. "Disaggregating International Organizations." Typescript, University of California, San Diego.

URL: http://147.142.190.246/joomla/peio/files2011/papers/Gartzke,\%20Nordstrom,\%20Boehmer\%200

Geddes, Barbara, Joseph Wright and Erica Frantz. 2014. "Autocratic Breakdown and Regime Transitions: A New Data Set." Perspectives on Politics 12(2):313-331.

Goertz, Gary. 2006. Social Science Concepts: A User's Guide. Princeton: Princeton University Press.

Goldsmith, Benjamin E., Dimitri Semenovich, Arcot Sowmya and Gorana Grgic. 2017. "Political Competition and the Initiation of International Conflict: A New Perspective on the Institutional Foundations of Democratic Peace." World Politics 69(3):493531.

Gowa, Joanne and Raymond Hicks. 2017. "Commerce and Conflict: New Data about the Great War." British Journal of Political Science 47(3):653-674.

Greenberg, Michael. 1969. British Trade and the Opening of China 1800-1842. Cambridge: Cambridge University Press.

Hegre, Håvard. 2014. "Democracy and armed conflict." Journal of Peace Research 51(2):159172. 
Hegre, Håvard, Michael Bernhard and Jan Teorell. 2020. "Civil society and the democratic peace." Journal of Conflict Resolution 64(1):32-62.

Hilferding, Rudolf. 1985. Finance Capital: A Study of the Latest Phase of Capitalist Development. London: Routledge.

Hobsbawm, Eric. 2010a. Age of Capital: 1848-1875. London: Hachette UK.

Hobsbawm, Eric. 2010b. Age of Empire: 1875-1914. London: Hachette UK.

Hobson, John Atkinson. 1902. Imperialism: a study. J. Pott.

Hyde, Susan D and Elizabeth N Saunders. 2020. "Recapturing Regime Type in International Relations: Leaders, Institutions, and Agency Space." International Organization 74(2):363-395.

Knutsen, Carl Henrik, Jan Teorell, Agnes Cornell, John Gerring, Haakon Gjerløw, SvendErik Skaaning, Tore Wig, Daniel Ziblatt, Kyle Marquardt, Dan Pemstein and Brigitte Seim. 2019. "Introducing the Historical Varieties of Democracy Dataset: Patterns and Determinants of Democratization in the Long 19th Century." Journal of Peace Research $56(3): 440-451$.

Lenin, Vladimir. 1999. Imperialism as the highest stage of capitalism. London: Resistance books.

Lensink, Robert, Niels Hermes and Victor Murinde. 2000. "Capital flight and political risk." Journal of International Money and Finance 19(1):73-92.

Levy, Jack S and William R Thompson. 2011. Causes of war. John Wiley \& Sons.

Lipson, Charles. 1985. Standing Guard. Protecting Foreign Capital in the Nineteenth and Twentieth Century. Berkeley: University of California Press.

Luxemburg, Rosa. 1913. The accumulation of capital. London: Routledge.

Manchester, William. 2017. The arms of Krupp: The rise and fall of the industrial dynasty that armed Germany at war. Boston: Little, Brown.

Moore, Barrington. 1966. Social Origins of Democracy and Dictatorship: Lord and Peasant in the Making of the Modern World. Boston: Beacon Press. 
Mousseau, Michael. 2013. "The Democratic Peace Unraveled: It's the Economy." International Studies Quarterly 57(1):186-197.

Oster, Emily. 2019. "Unobservable selection and coefficient stability: Theory and evidence." Journal of Business \&f Economic Statistics 37(2):187-204.

Pemstein, Daniel, Kyle L Marquardt, Eitan Tzelgov, Yi-ting Wang, Joshua Krusell and Farhad Miri. 2018. "The V-Dem measurement model: latent variable analysis for crossnational and cross-temporal expert-coded data." Varieties of Democracy (V-Dem) Project.

Reiter, Dan and Allan C Stam. 2003. "Identifying the culprit: Democracy, dictatorship, and dispute initiation." American Political Science Review 97(2):333-337.

Rueschemeyer, Dietrich, Evelyne Huber Stephens and John D. Stephens. 1992. Capitalist Development and Democracy. Chicago, IL: University of Chicago Press.

Russett, Bruce and John Oneal. 2001. Triangulating peace: Democracy, interdependence, and international organizations. London, New York: W.W. Norton.

Sarkees, Meredith Reid and Frank Wayman. 2010. Resort to War: 1816 - 200\%. New York: CQ Press.

Scheidel, Walter. 2018. The Great Leveler. Violence and the Global History of Inequality from the Stone Age to the Twenty-First Century. Princeton: Princeton University Press.

Schneider, Gerald. 2017. "Capitalist Peace Theory: A Critical Appraisal." Oxford: Oxford Research Encyclopedias (Politics).

URL: http://politics.oxfordre.com/view/10.1093/acrefore/9780190228637.001.0001/acrefore9780190228637-e-314

Schneider, Gerald and Nils Petter Gleditsch. 2010. "The Capitalist Peace: The Origins and Prospects of a Liberal Idea." International Interactions 36(2):107-114.

Schumpeter, Joseph A. 1955/1919. Imperialism and Social Classes. Cleveland: World Publishing.

Signorino, Curtis S and Jeffrey M Ritter. 1999. "Tau-b or not tau-b: Measuring the similarity of foreign policy positions." International Studies Quarterly 43(1):115-144. 
Svolik, Milan W. 2012. The Politics of Authoritarian Rule. Cambridge: Cambridge Univerisity Press.

Teorell, Jan, Michael Coppedge, Svend-Erik Skaaning and Staffan I Lindberg. 2019. "Measuring Polyarchy Across the Globe, 1900-2017." Studies in Comparative International Development 54:71-95.

Varian, Hal R. 1992. Microeconomic Theory. New York: W.W. Norton.

Vidal, Gore. 2007. Dreaming War: Blood for Oil and the Cheney-Bush Junta. New York: Bold Type Books.

Waltz, Kenneth N. 1959. Man, the State, and War: A Theoretical Analysis. New York: Columbia University Press.

Weeks, Jessica L. 2008. "Autocratic audience costs: Regime type and signaling resolve." International Organization 62(1):35-64.

Weeks, Jessica L. 2012. "Strongmen and Straw Men: Authoritarian Regimes and the Initiation of International Conflict." American Political Science Review 106(2):326-347.

Weeks, Jessica L.P. 2014. Dictators at War and Peace. Ithaca: Cornell University Press.

Wong, John Y. 2000. "The limits of naval power: British gunboat diplomacy in China from the Nemesis to the Amethyst, 1839-1949." War \& Society 18(2):93-120. 


\section{A Online Appendices}

This online appendix contains sevens sections where we present descriptive statistics or report results from several additional tests mentioned, but not reported in tables, in the main paper. First, we present descriptive statistics on our key variables. Second, we report the results from specifications including dyad-fixed effects. Third, we perform the same estimation and plot of split-sample results as we did in Figures 6 and 7 for total trade in the main text, but using exports and imports to split the sample. Fourth, we take out all observations relating to WWII and WWI from our data and re-estimate our benchmark specifications. Fifth, we estimate split-sample models on democracies and dictatorships, splitting the sample according to regime in the initiating country. Sixth, we investigate results for different combinations of major-minor power status in the initiator and target countries. Finally, we replicate our benchmark models, but by using different ways of operationalizing the presence or importance of business elites in the support coalition, using the continuous measure of support coalition presence as well as V-Dem's 'most important support group' coding. 


\section{A.1 Descriptive statistics}

\begin{tabular}{|c|c|c|c|c|c|}
\hline & \multicolumn{5}{|c|}{ (Summary stats for variables in the baseline model) } \\
\hline & count & mean & sd & $\min$ & $\max$ \\
\hline MID initiation & 1374616 & .0018274 & .0427093 & 0 & 1 \\
\hline Business elites & 1229440 & .4015641 & .4902148 & 0 & 1 \\
\hline Business elites (dyad) & 1099284 & .1651893 & .3713515 & 0 & 1 \\
\hline Polyarchy (dyad) & 1351538 & .2371735 & .2002768 & .008 & .92 \\
\hline Num. groups in coalition & 1374616 & 9.373664 & 3.2117 & 0 & 13.33333 \\
\hline Support group size & 1224821 & .4956682 & 1.163256 & -2.912 & 2.6 \\
\hline GDP & 1364085 & 9.851099 & 1.958225 & 4.9662 & 16.13932 \\
\hline Population & 1364085 & 8.867382 & 1.637406 & 4.137793 & 14.09482 \\
\hline CINC & 1374616 & .0097898 & .0297037 & $3.00 \mathrm{e}-06$ & .383864 \\
\hline Contiguity & 1374616 & 5.32388 & 1.82822 & 0 & 6 \\
\hline $\mathrm{L}($ distance $)$ & 1374616 & 7.72548 & 3.005801 & -9.21034 & 9.421168 \\
\hline Peace years & 1374616 & 20.63843 & 24.13418 & -9 & 185 \\
\hline Peace years ${ }^{2}$ & 1374616 & 1008.403 & 2383.814 & 0 & 34225 \\
\hline Peace years ${ }^{3}$ & 1374616 & 70705.37 & 301706.9 & -729 & 6331625 \\
\hline
\end{tabular}




\section{A.2 Models with dyad-fixed effects}

Table A.1: Dyad-fixed effects models

\begin{tabular}{lcccc}
\hline \hline & $(1)$ & $(2)$ & $(3)$ & $(4)$ \\
& $\mathrm{m} 1$ & $\mathrm{~m} 2$ & $\mathrm{~m} 3$ & $\mathrm{~m} 4$ \\
\hline Business elites i & -0.0480 & -0.000285 & 0.488 & -0.000698 \\
& $(-0.49)$ & $(-1.53)$ & $(0.33)$ & $(-0.25)$ \\
Business elites i & 0.0986 & 0.000156 & $3.694^{*}$ & $0.00809^{* *}$ \\
& $(0.98)$ & $(0.84)(2.43)$ & $(2.94)$ & \\
Business elites (dyad) & $-0.480^{* * *}$ & $-0.000859^{* * *}$ & $-92.80^{* * *}$ & $-0.237^{* * *}$ \\
& $(-3.70)$ & $(-3.59)$ & $(-4.08)$ & $(-5.14)$ \\
\hline $\mathrm{N}$ & 55739 & 1037428 & 55916 & 1049278 \\
\hline \hline$t$ statistics in parentheses & & & & \\
$* p<0.05, * *$ & $p<0.01,{ }^{* * *} p<0.001$ & & &
\end{tabular}

Notes: ${ }^{*} p<0.05,{ }^{* *} p<0.01,{ }^{* * *} p<0.001 . T$ and $Z$ statistics in parentheses. Standard errors clustered on dyads. All models include the covariates in table 1 model 2 (excluded from table). 


\section{A.3 Separating between exports and imports}

This section replicates our benchmark model on samples split by whether the initiating state is a high or low (above or below median) exporter to the target state, and samples split in the same way by imports. Figure A.1 and figure A.2 displays results for exports and figure A.3 and A.4 for imports. These plots reveal that the relationship between business elites in $i$ increases the risk of conflict-initiation against non-business elite regimes when $i$ is a high exporter to $j$, but not otherwise (A.1. The pacifying effect of business-business dyads does not seem to depend on high export dyads (A2).

Second, the plots for imports indicate that business elites increase conflict initiation (against non-business regimes) when the initiator has high imports from the target. Figure A.4 shows that business-business pairings are pacifying when imports are high but not when they are low. This is in line with our expectation that business elites conduce peaceful relations with trading partners that also have business oriented policies.

Figure A.1: Predicted probabilities for Business elites $_{i}$ when Business elites ${ }_{j}=0$, in high(left) or low (right) exports from the initating state
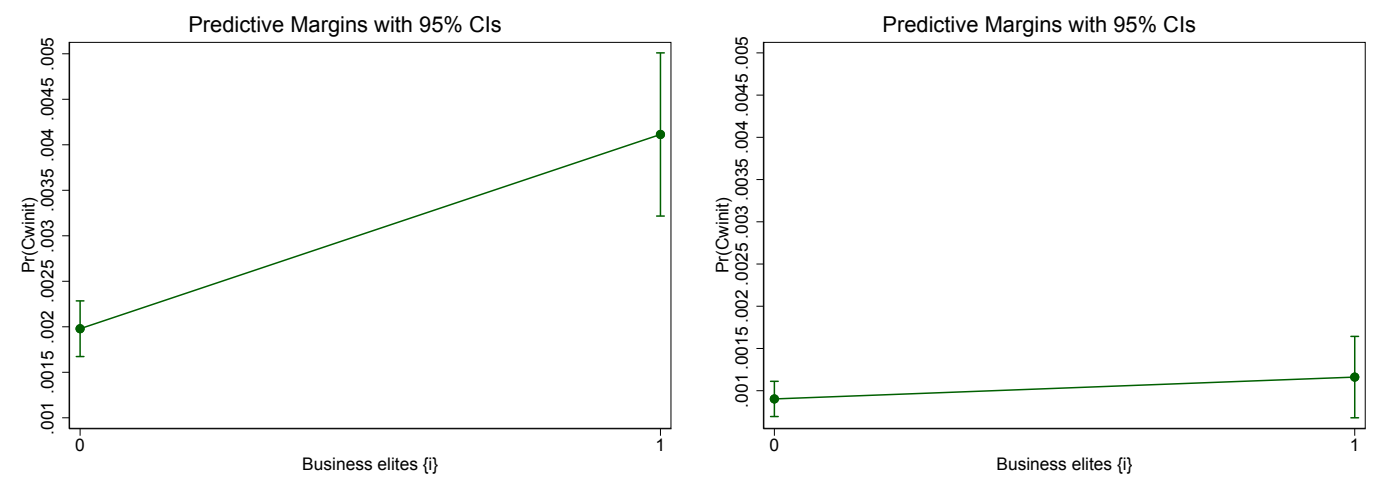
Figure A.2: Predicted probabilities for Business elites ${ }_{i}$ when Business elites ${ }_{j}=1$, in high(left) or low (right) exports from the initating state
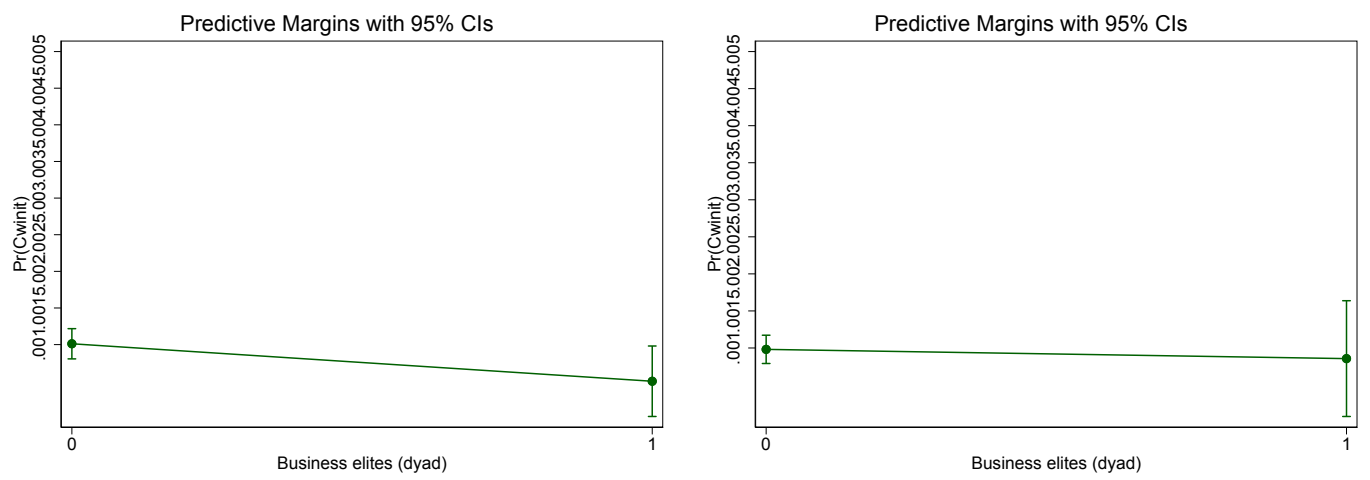

Figure A.3: Predicted probabilities for Business elites ${ }_{i}$ when Business elites ${ }_{j}=0$, in high(left) or low (right) imports to the initating state
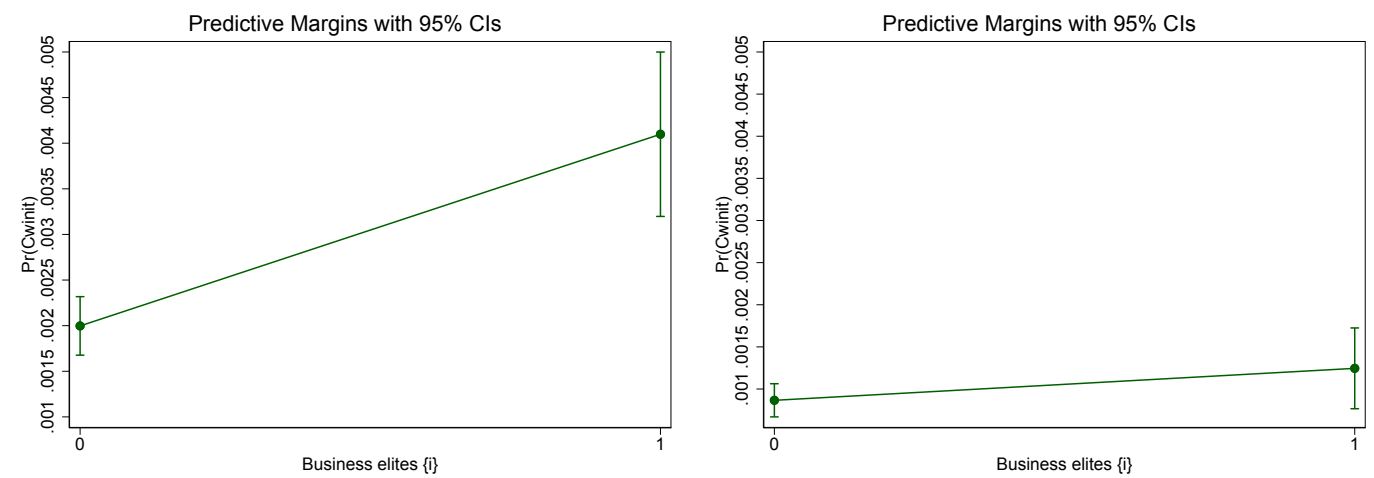
Figure A.4: Predicted probabilities for Business elites $_{i}$ when Business elites ${ }_{j}=1$, in high(left) or low (right) imports to the initating state
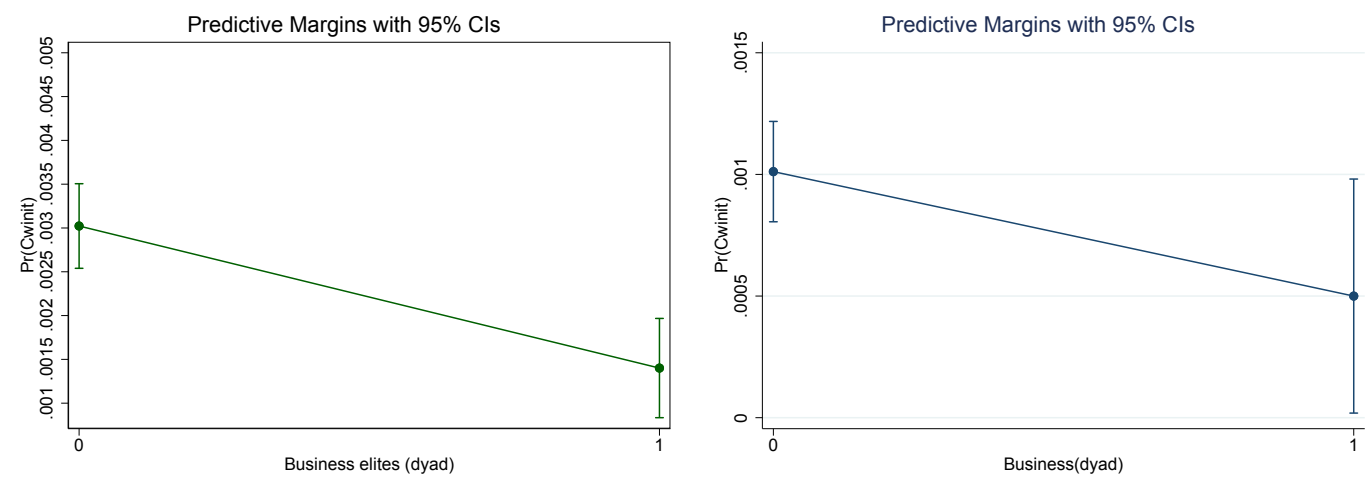


\section{A.4 WWI and WWII}

We estimate models where we remove WWI and WWII from the sample. We do this in a rather blunt way by simply removing all years where WWI and WWII occured (1914-1918 and 1939-1945), since it would be problematic to count and treat conflict codings in these (conflict-rich) periods as unrelated. Our findings are very similar to the main results in these models as well.

Table A.2: Baseline models excluding WWI and WWII

\begin{tabular}{lcccc}
\hline \hline & Logit & Logit & Logit & LPM \\
& 1.1 & 1.2 & 1.3 & 1.4 \\
\hline Business elites i & $0.587^{* * *}$ & $0.706^{* * *}$ & -0.0398 & -0.000244 \\
& $(3.69)$ & $(3.90)$ & $(-0.28)$ & $(-0.97)$ \\
Business elites j & $0.785^{* * *}$ & $0.873^{* * *}$ & $0.311^{*}$ & $0.000664^{* *}$ \\
& $(4.86)$ & $(4.63)$ & $(2.10)$ & $(2.63)$ \\
Business elites (dyad) & $-0.823^{* *}$ & $-0.790^{* *}$ & $-0.629^{* *}$ & $-0.00144^{* * *}$ \\
& $(-3.03)$ & $(-2.98)$ & $(-3.27)$ & $(-3.86)$ \\
\hline $\mathrm{N}$ & 1069172 & 1027358 & 46932 & 1027358 \\
\hline \hline$t$ statistics in parentheses & & & & \\
${ }^{*} p<0.05,{ }^{* *} p<0.01,{ }^{* * *} p<0.001$ & & &
\end{tabular}

Notes: ${ }^{*} p<0.05,{ }^{* *} p<0.01,{ }^{* * *} p<0.001 . T$ and $Z$ statistics in parentheses. Standard errors clustered on dyads. 


\section{A.5 Democracy and non-democracy initiators}

Table A.3: Benchmark models replicated on democracy and non-democracy initiators

\begin{tabular}{lcccccccc}
\hline \hline & Logit & Logit & Logit & LPM & Logit & Logit & Logit & LPM \\
& 1.1 & 1.2 & 1.3 & 1.4 & 1.5 & 1.6 & 1.7 & 1.8 \\
& Democratic $i$ & Democratic $i$ & Democratic $i$ & Democratic $i$ & Autocratic $i$ & Autocratic $i$ & Autocratic $i$ & Autocratic $i$ \\
\hline Business elites i & $0.664^{* *}$ & $0.453^{*}$ & -0.122 & 0.000125 & 0.220 & 0.399 & $-0.534^{*}$ & $-0.00122^{* *}$ \\
& $(3.23)$ & $(2.12)$ & $(-0.52)$ & $(0.33)$ & $(1.04)$ & $(1.59)$ & $(-2.21)$ & $(-2.64)$ \\
Business elites j & 0.300 & 0.189 & -0.573 & $-0.000966^{*}$ & $0.733^{* * *}$ & $0.968^{* * *}$ & $0.422^{*}$ & $0.00129^{* * *}$ \\
& $(1.12)$ & $(0.62)$ & $(-1.79)$ & $(-2.41)$ & $(4.87)$ & $(5.35)$ & $(2.21)$ & $(3.37)$ \\
Business elites (dyad) & -0.717 & -0.696 & -0.177 & $-0.00155^{* *}$ & -0.471 & -0.560 & $-0.591^{*}$ & $-0.00143^{*}$ \\
& $(-1.91)$ & $(-1.83)$ & $(-0.51)$ & $(-2.80)$ & $(-1.39)$ & $(-1.69)$ & $(-1.97)$ & $(-2.22)$ \\
\hline Baseline controls & $\checkmark$ & $\checkmark$ & $\checkmark$ & $\checkmark$ & $\checkmark$ & $\checkmark$ & $\checkmark$ & $\checkmark$ \\
Region-dummies & $\checkmark$ & $\checkmark$ & $\checkmark$ & & $\checkmark$ & $\checkmark$ & $\checkmark$ \\
Decade-dummies & $\checkmark$ & $\checkmark$ & $\checkmark$ & $\checkmark$ & $\checkmark$ & $\checkmark$ & $\checkmark$ & $\checkmark$ \\
Dyad-FE & & & & & $\checkmark$ & & & $\checkmark$ \\
\hline $\mathrm{N}$ & 550161 & 527620 & 20076 & 527620 & 541209 & 520866 & 25575 & 520866 \\
\hline \hline
\end{tabular}

$t$ statistics in parentheses

${ }^{*} p<0.05,{ }^{* *} p<0.01,{ }^{* * *} p<0.001$

Notes: ${ }^{*} p<0.05,{ }^{* *} p<0.01,{ }^{* * *} p<0.001 . T$ and $Z$ statistics in parentheses. Standard errors clustered on dyads. Joint democracy and non-democracy defined by taking the median joint-democracy score as the cutoff, which is a polyarchy score of .20 


\section{A.6 Major power status}

We replicate our benchmark for different combinations of major-minor power status in the dyad in table A.4 below. This shows that the link between business-elites in the initiating country's support coalition (when the target does not have a business-elite coalition) and conflict exists for major powers, as initiators but not minor ones. As discussed in the paper, this suggests that business elites can drive conflict mainly when they carry political clout in powerful states. The dyadic finding also seems to be most robust for dyads where both countries are major powers.

Table A.4: Benchmark models replicated on different constellations of major vs. minor powers

\begin{tabular}{|c|c|c|c|c|}
\hline & (1) & $(2)$ & $(3)$ & (4) \\
\hline Power status & Major-major & Major-minor & Minor-major & Minor-minor \\
\hline \multirow[t]{2}{*}{ Business elites i } & $0.965^{* *}$ & $1.108^{* * *}$ & -0.194 & -0.217 \\
\hline & $(3.19)$ & $(4.57)$ & $(-0.52)$ & $(-1.21)$ \\
\hline \multirow[t]{2}{*}{ Business elites $\mathrm{j}$} & 0.322 & 0.165 & $1.479^{* * *}$ & 0.289 \\
\hline & $(1.16)$ & $(0.57)$ & $(4.54)$ & (1.69) \\
\hline \multirow[t]{2}{*}{ Business elites (dyad) } & $-0.869^{*}$ & -0.462 & -0.398 & -0.296 \\
\hline & $(-2.27)$ & $(-1.37)$ & $(-0.83)$ & $(-0.86)$ \\
\hline Region-FE & $\checkmark$ & $\checkmark$ & $\checkmark$ & $\checkmark$ \\
\hline Decade-FE & $\checkmark$ & $\checkmark$ & $\checkmark$ & $\checkmark$ \\
\hline $\mathrm{N}$ & 3548 & 53712 & 50022 & 981092 \\
\hline
\end{tabular}

Notes: ${ }^{*} p<0.05,{ }^{* *} p<0.01,{ }^{* * *} p<0.001 . T$ and $Z$ statistics in parentheses. Major power status comes from the Correlates of War Dataset. 


\section{A.7 Different measures of business elites in support coalitions}

In this section, we replicate our main analyses, but trying out different ways of measuring the presence or importance of business-elites in support coalitions. Columns 1-2 use the original, continuous V-Dem measure, where the presence of business-elites are coded by averaging country experts scores. The scale ranges from 0 to 1 . To illustrate, a 1-score now indicates full consensus among experts on the presence of business elites in the support coalition, 0 indicates full consensus on their absence, and a score of 0.5 indicates that exactly half of the country experts coded business elites as part of the support coalition for a regime, in a particular year. These models yield similar estimates to our main results. Next, in Columns 3-4, we use the measure capturing whether business elites constitute the "most important" support group, as coded by V-Dem experts, where "most important" indicates that the support of this group is most pertinent for the regime's ability to stay in power. This measure has much less variation over time than the measures registering presence of a group in the support coalition. Forn many observations, the military are consistently coded as the "most important", and this is especially the case for non-democracies. It is therefore not unsurprising that the precision of our estimated coefficients is weakened. Results generally point in the same direction, but the interactive coefficients fall short of statistical significance at conventional levels. Finally, we use the stricter measure of business elite presence in the support coalition, requiring consensus among $\mathrm{V}$-Dem expert coders on their presence for coding a regime as "business-supported". Once again, results are very clear for the monadic expectation - business-supported regimes are more likely to initiate conflicts - whereas the dyadic pacifying effect is less precisely estimated, with the interactive coefficients obtaining t-values around 1.5. 
Table A.5: Baseline models replicated with two different measures of business elite presence

\begin{tabular}{lcccccc}
\hline \hline \multirow{2}{*}{ Measure } & \multicolumn{3}{c}{ Logit } \\
& \multicolumn{2}{c}{ Sliding scale } & Most important group (binary) & \multicolumn{2}{c}{ Threshold ==1 } \\
& 1.1 & 1.2 & 1.3 & 1.4 & 1.5 & 1.6 \\
\hline Business elites i & $0.624^{* * *}$ & $0.753^{* * *}$ & $0.492^{* * *}$ & $0.525^{* * *}$ & $0.447^{* * *}$ & $0.557^{* * *}$ \\
& $(4.17)$ & $(4.40)$ & $(4.16)$ & $(4.07)$ & $(3.78)$ & $(4.23)$ \\
& $0.760^{* * *}$ & $0.842^{* * *}$ & -0.213 & -0.180 & $0.569^{* * *}$ & $0.658^{* * *}$ \\
Business elites j & $(4.96)$ & $(4.72)$ & $(-1.28)$ & $(-1.06)$ & $(4.30)$ & $(4.26)$ \\
& $-0.891^{* * *}$ & $-0.858^{* * *}$ & -1.025 & -0.918 & -0.295 & -0.291 \\
Business elites (dyad) & $(-3.39)$ & $(-3.36)$ & $(-1.53)$ & $(-1.36)$ & $(-1.59)$ & $(-1.53)$ \\
& 1092232 & 1049278 & 1107288 & 1061268 & 1092232 & 1049278 \\
\hline N & $\checkmark$ & $\checkmark$ & $\checkmark$ & $\checkmark$ & $\checkmark$ & $\checkmark$ \\
\hline Baseline controls & $\checkmark$ & $\checkmark$ & $\checkmark$ & $\checkmark$ & $\checkmark$ & $\checkmark$ \\
Region-dummies & $\checkmark$ & $\checkmark$ & $\checkmark$ & $\checkmark$ & $\checkmark$ & $\checkmark$ \\
Decade-dummies & 1092232 & 1049278 & 1107288 & 1061268 & 1092232 & 1049278 \\
\hline N & & & & & $\checkmark$ & $\checkmark$ \\
\hline \hline
\end{tabular}

$z$ scores in parentheses

${ }^{*} p<0.05,{ }^{* *} p<0.01,{ }^{* * *} p<0.001$ 